


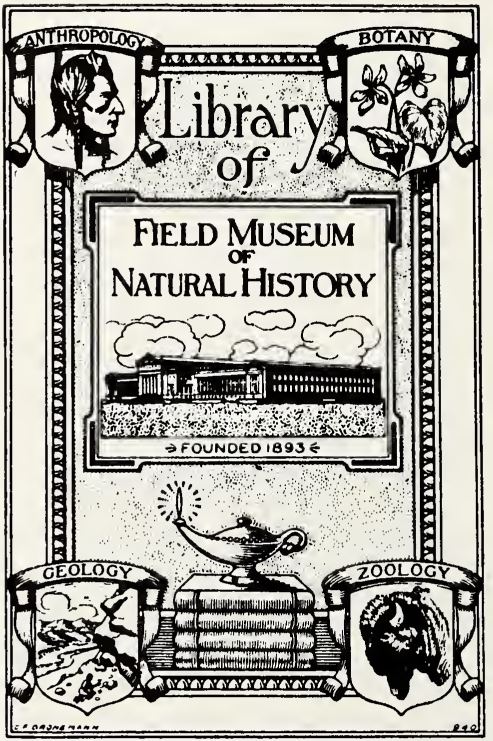


Digitized by the Internet Archive in 2015

https://archive.org/details/alassioitsflora00vinc 




$$
\begin{aligned}
& \text { Sift of Miss Paula Serard } \\
& \text { Dmard } 1963
\end{aligned}
$$

ALASSIO AND ITS FLORA 



\section{ALASSIO AND ITS FLORA}

BY

\section{Dr. VINCENZO NAMI}

Member of the British Medical Association

M. D. of the University of Turin

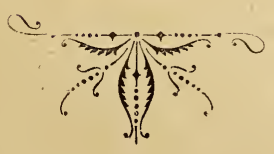

ALASSIO

PRINTED BY JOSEPH OTTINO.

1892 
QR
316
$N 5$

All rights reserved

Proprietà letteraria 
ALLA SUA CARA CITTÀ DI ALASSIO

DEDICA ED OFFRE

QUESTO SUO PICCOLO LAVORO

L'AUTORE. 



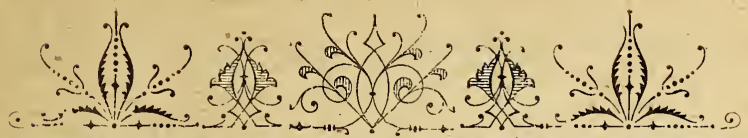

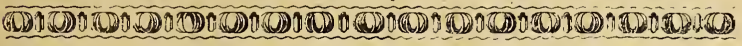

\section{PREFACE}

HIs little volume does not pretend to be a contribution to science. In offering to the visitor the humble result of my botanical studies, my sole aim has been to commend Alassio, my beloved birthplace and home.

If I have found fault, I hope my fellowcitizens will deem that my one motive is an earnest wish for improvement. Defective however as the town is in some matters, which regard the general health and welfare of the people, the average mortality is less than that of 
most English towns notwith standing the fact that so many invalids come here alrearly enfeebled by mortal distempers.

I trust that my fellow Alasisians will be gratified to possess what I may at least call an index of the plants of Alassio, which written by one of themselves may furnish them the example of not leaving to strangers the task of setting forth the charms of their beautiful sunny spot.

The book is written in English because it is the language of the greater part of our visitors, and because it is the English who are. especially interested in planthunting. But even an Alassian hereafter induced to take up the same pursuit will find little difficulty in using this work, consisting as it does, chiefly of technical terms which are common to all languages. With such additional help, I should be able to make a more complete Flora, with fuller descriptions and records of places where the various plants may be found.

I have even thought of adding a map of the territory, divided into numbered squares, and annexing to the name of each 
plant the number of the square, in which it may be found: my medical cares have. compelled me to leave this undone, but, quod differtur. non aufertur, and I hope yet to carry this idea into effect.

Alassio, 1 May 1892.

Dr. Vincenzo Nam.

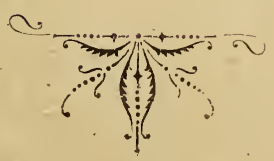



AIASSIO 



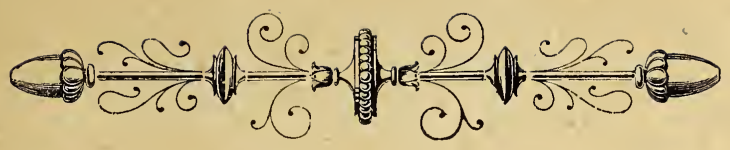

\title{
ALASSIO
}

\author{
$++$ \\ GEOGRAPHICAL POSITION - CLIMATE - \\ PUBLIC HEALTH
}

The author of the following short account of Alassio hopes that the fact of his being a native of the place, will not cause his readers to be mistrustful of what he tells them about it.

Though prepared to admit that one is prone to think too well of his own birthplace, the author hopes that, fond as he is of his native Alassio, he will not be deemed to make any excessive claims on her behalf, for this reason at least, if for no better one, that he is about to speak of positive facts, which, if untrue might 
be easily refuted; and in this summary description he will proceed with only cursory notice of his own opinions, allowing chief space to demonstrable proof, while in treating that part of his subject which is of interest to the botanist, he will naturally be outside the promptings of party feeling. - If furthermore he has had to speak with harshness of aught which appeared to deserve it, he hopes that his fellowtownsmen will forgive him, bearing in mind that the wish to avoid the semblance of partisanship was his inducement to keep no unpleasant truth concealed, seeing that assertions are of but small weight which proceed from one blinded by partiality; and considering besides that nothing would spur us to mend our own. faults, wherever it be possible, so much as a previous confession of them.

In a rapid trip which I have made in that part of the enchanted western Riviera which reaches from Alassio to Nice, I have been surprised that money and treasure. 
should have been lavished on places certainly not superior. to Alassio; none of which, it may safely be said, presents an environment of mountains so pleasing to the sight, or so capable of giving protection against the winds by their height, nearness, and continuity.

The mountains from Capo Santa Croce to Capo Mele are uninterrupted. Monte Bignone, m. 520 in height extends with a gradual ascent to Pisciavino, m. 597; from this to Madonna della Guardia or Monte Tirazzo there are only $11 \mathrm{~m}$. of difference; and from this, m. 586, there is a gradual descent to the end of Capo Mele, m. 220, the most projecting point of Liguria, on which there is a first class lighthouse, and where at the present time a semaphore is being constructed, protected by fortifications. These two capes, Santa Croce and Capo Mele, form the extremities of a vast semicircle, whose principal axis is turned to S. E., completely closed on the north side by a lofty natural wall of uniform height, and has a cord of seven kilom. in length. A small rib descends from the prin- 
cipal chain, the mountain called Fasce Grasse, which arriving at the sea, projects a very little distance into it, and takes the name of Porto Salvo, dividing the main gulf into two unequal parts, of which the smaller, or southernmost, belongs to Laigueglia, and the larger, which measures three and a half kilom., to Alassio the buildings of which extend for almost its entire length. It is said that Napoleon Bonaparte called it Ville Longue, and its geographical position has won for it with mariners the name of the Gulf of peace, because here the largest fleet could anchor in safety from all winds.

Numerous small hills clad with groves of olive and pine, slope gently down to the sea, and many rivulets enriched with a great variety of plants even in winter, bear their limpid waters to the plains of the deep.

Above the railway in the most sheltered spots, rise here and there numerous small villas belonging chiefly to English families, who admiring this spot so privileged by nature have bought the ground 
and built their residences there. The Alassians themselves long since delighted with the beauty of their native place, have built a great many houses in the country round about, and one may say that however poor a proprietor may be, there is not one who does not possess his own country residence.

I cannot therefore understand the feverish activity, the innumerable villas, the immense sums lavished on localities, which, as one must allow, are sheltered, but are small, arid, and wild; where artificial beauty contrasts so strongly with the barren rocks which are forced to smile on such unnatural pomp.

Alassio has the following geographical. position calculated by the Meteorological Observatory of the Municipal College:

Longitude W. of Rome $4^{\circ} 17^{\prime} 50^{\prime \prime}$

Longitude E. of Greenwich $0^{\mathrm{h}} 32^{\mathrm{m}} 44^{\mathrm{s}}$

Latitude N. $44^{\circ} 0^{\prime} 1^{\prime \prime}$.

Distant kilom. 91 from Genoa, and 61 from Ventimiglia; it is about halfway between Genoa and Nice. From the summary of the meteorological observations 
taken by the Rev. Professor Don L. Rocca, Director of the Observatory, and also Principal of the Municipal College of Alassio, and published in 1886, I draw the following figures as the average of observations continued during four vears, 1851-S283-84-85:

November average temper..$^{\text {re }}$, cent. ${ }^{\text {de }} 12^{\circ} 61$

December : 》

January »

February

March

April

$\gg$
$\gg$
$\gg$

$\gg$

$\gg$

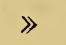

» $\quad 9^{\circ} 70$

$\gg \quad \gg \quad 9^{\circ} 87$

$\gg \quad \gg 10^{\circ} 54$

$\gg \quad \gg 11^{\circ} 78$

$\gg \quad 14^{\circ} 03$

Average in winter cent de $^{\circ} 11^{\circ} 42$ equal to $52^{\circ} .55$ Fahrenheit. From this table it will be seen that the coldest month is December with an average of $9^{\circ} .70$ cent te; $^{\text {de }}$ or $49^{\circ} .49$ Fahrenheit. Therefore when the temperature is so high in the open air one can understand that persons, however delicate, may always pass the day, or, at least, the greater part of it, out of doors without incurring the least danger from cold, particílarly if they wear sufficient 
clothing, and select that which is a non conductor of heat, and also if they walk where they are sheltered by the mountains where the average temperature would be much higher; the figures given being those of the Observatory which is in the plain and certainly not the most sheltered spot.

Public health. - The mortality in Alassio is very much under the average of the other Italian towns; and the last six years gave the following figures.

Population to the $1^{\text {st }}$ January $1882-$ 5789 :

$\begin{array}{ccc}1884 & \text { Deaths } & 119 \\ 1885 & \gg & 111 \\ 1886 & \gg & 103 \\ 1887 & \gg & 117 \\ 1888 & \gg & 132 \\ 1889 & \gg & 121\end{array}$

Annual average 20, 23 per 1000.

Considering the increase in the population which may be attributed to the Italian labourers who have come here in search of work, and to the strangers in search of health, as well as to 300 persons be- 
tween the College of Don Bosco, and the female College whose death-rate is included in the average rate, the mortality of this town may be estimated at 18 per 1000 , or even less.

Statistics of the mortality in the cities of Italy published by order of the ministry, give for the year 1886 a mortality of 22.35 for Sanremo; now in that same year the mortality in Alassio was but 17.79 . It should be noted that of those six years, one, viz. 1887, was the fatal year of the earthquake in Alassio, when three persons were found dead under the ruins, and more than fifteen died from the indirect consequences of the earthquake: the Civic Hospital was crowded, and nearly every day invalids were received of whom several already delicate, and with health still further impaired by a life of privation and exposure to inclement weather in badly made huts, perished soon after the famous date of the $23^{\text {rd }}$ of February. Notwithstanding all this, the deaths came only to 117 , scarcely exceeding by 14 those of the preceeding year. 
We give here a table of the mortality in the different towns of Italy and also in Great Britain.

$\begin{array}{lllll}\text { Melfi } & 74.62 & \text { Milano } & 32.19 \\ \text { Barletta } & 66.27 & \text { Genova } & 31.55 \\ \text { Brindisi } & 64.14 & \text { Napoli } & 31.2 \\ \infty \\ \infty \\ \text { Altamura } & 55.61 & \text { Roma } & 30.41 \\ \text { Cremona } & 50.57 & \text { Savona } & 27.36 \\ \text { Foggia } & 40.57 & \text { Torino } & 26.6 \\ \text { Bari } & 39.11 & \text { Sanremo } & 22.35 \\ \text { Bergamo } & 35.19 & \text { Alassio } & 17.79 \\ \text { Venezia } & 33.3 & & \end{array}$

Years 1885 and 1886 - Average mortality per thousand:

$\begin{array}{ll}\text { Manchester } & 25.4 \\ \text { Liverpool } & 23.8 \\ \text { Salford } & 21.6 \\ \text { Leeds } & 20.9 \\ \text { London } & 19.8 \\ \text { Birmingham } & 19.3 \\ \text { Edinburgh } & 18.7 \\ \text { Hull } & 18 .\end{array}$

Alassio 1885 and 1886, mortality 18.46. 
The intelligent and practical reader after having read and considered the above tables will without doubt be convinced of the salubrity of our climate, as we have not only a lower average deathrate than the other Italian cities, but even than the principal English ones, where few things are left untried which may benefit the public health; for it iswell known that nothing increases mortality so much as neglect of hygienic measures. And yet in this period that. I have had under examination, there were various causes at work, which had a bad influence on the public health. (In the winter of 1884-85 we had cases of Typhoid fever and of Pneumonia, which brought alarm into not a few of our families; the misfortune of the earthquake of 1887, and some other causes unnecessary to enumerate).

If the hygienic measures proposed to our Corporation to improve the sanitary condition of our town, and so give it immunity from epidemies, were adopted, such as providing it with drinkable water instead of that which, defiled by the subsoil is drawn from the existing wells; a most necessary 
precaution to avoid the infection of certain diseases; the reception of the contents of the present cesspools in watertight receptacles; the abolition of some open sewers, and the erection of a small sickhouse to insulate the first cases of contagious diseases, I do not hesitate affirm to that, if all this were done, the mortality in our town would be reduced to 7 or 8 per $1(100$; a wonderful fact which it would be a sin to neglect, when it could be attained so easily.

I owe to the kindness of the Marquis Ippolito Riccardo Gallo the following historical notes which are only extracts from his valuable work Storia di Alassio and I take this opportunity of thanking him for the use of the same. 



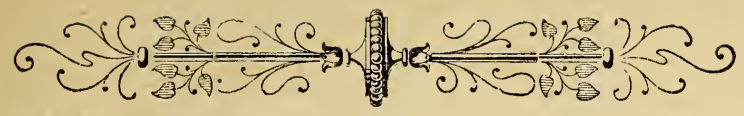

\title{
HISTORICAL SKETCH
}

\author{
OF ALASSIO
}

An infinite number of writer's of Ligurian history have busied themselves about the origin of Alassio. Leaving apart the lengthened discussions concerning the Aleramican legend, and the Benedictine fathers, and Lamium, and omitting the opinion that makes Saracens, Catalans, and Coralins, by turn, the founders of Alassio, we affirm that the foundation is not to be attributed to any one particular person but that it arose from a variety of causes and circumstances. The frequent incursions of the barbarians, the plagues, the famines, the ruin - and desolation that afflicted the Ligurian countries from A. D. 400 to A. D. 800 induced the Ligurians and especially the 
Ingauni to take refuge and hide themselves in the mountains. It is to this continual succession of massacres, destruction and flights, etc., that we attribute the origin of Alassio as it appeared in the beginning of A. D. 900 on the hill still called the Castello or Madonna delle Grazie.

In the beginning of the year 1000 came the Benedictines and founded on the island of Gallinaria the Abbey of Santa Maria and San Martino, as well as the priory of Santa Croce on the cape of that name, the ruins of which church are still to be seen on the promontory to the east of Alassio. Profiting by the receding of the sea they built a church under Belvedere behind the modern town, and dedicated it to Sant'Ambrogio. The small size of the village, the ignorance of the people, and the great esteem in which the clergy were then held, were the causes that gave the civil and political supremacy over the new town into the hands of the monks of Gallinara.

But

Human and beautiful things fade and pass away 
and thus the Benedictine institution fell into decay so that in A. D. 1303 we have the famous deed of sale of the abovenamed supremacy in favour of Albenga. This document a thousand times repudiated as false by the ancient Alassians, and which was the cause of so many struggles between the Alassians and the inhabitants of Albenga, scems to us also of doubtful authority.

Long before this sale towards the end of 1100 it is cortain that the stil! existing. brotherhood of Santa Caterina was formed in Alassio, and until the French revolution preserved the right of judicature over its members. To the piety of the Alassians of that tims are due the rural santuaries that are to be found on the hills around.

Thus Nostra Signora della Guardia was built on the site of a Roman fortress, across the Roman Consular road called Aurelia on Monte Tirasso at the end of the year 1200. Nostra Signora delle Grazie was rebuilt in 1266, San Rocco, San Bernardo, Nostra Signora della Neve (commonly called Del Vento), were eracted about the thir- 
teenth century. Between 1306 and 1310 was built the church of Nostra Signora della Caritâ, with an hospital annèxed and an asylum for pilgrims, containing twenty six beds, from which fact we conclude that the ancient Alassians besides being pious, delighted in acting generously to the poor and unfortunate.

At this time the seafaring profession commenced to be, if not the sole, at all events the principal occupation of the people of Alassio, and in 1358 we meet with two Alassian galleys in the famous enterprise of Zerbi under the command of Raffaele Adorno. At the same time the trade in coral was renowned as may be seen by many documents, the most ancient of which bears the date of 1428. In the same years however, the country having increased in trade, industry and population, the fatal quarrel between Alassio and Albenga broke out. But it pleased Heaven that Fra Giovanni Tagliacarne, coming to these parts to preach, succeeded, though but a poor friar, in pacifying all discord, and sealed a peace confirmed with solemn 
oaths between all Ingaunian Communities, expecially between the people of Alassio and Albenga on the $10^{\text {th }}$ June 1454. A few years after in 1458 on the suggestion of Beatified Giovanni da Capistrano arose the convent of Nostra Signora degli Angeti, now enlarged and occupied by the fraternity of Don Bosco. Arts and sciences also commenced to flourish in this century in Alassio, and a painting of an ancient Alassian is remembered in the choir of the M. O. at Porto Maurizio, executed by Giovanni Mairone.

The people of Albenga seeing the prosperity of Alassio, and the poverty of their own country, deserted their own dwellings towards the end of this century and the beginning of the following, and settled in Alassio. This produced a very considerable increase of population, and the country following the example of the Italian Republics began to elect its own councillors with a general parliament. Beside the quarrels with their neighbour Albenga, lively enmities divided the Alassian people, which were however calmed for the time 
by the creation of the parish church of Sant'Ambrogio restored and enlarged by the tax which the commune of Albenga had levied on the Alassians of $5000 \mathrm{du}-$ cats of gold. Danger united the different parties and the Alassians, having armed themselves as well as they could, found themselves under the walls of Albenga in . May 1513, where if they did not succeed in burning the city as they had intended, they retired in good order after a sanguinary struggle and after having obtained an administrative independence which was followed by freedom in politics, or rather a state of dependence upon the Commune of Genoa.

About this time the Alassians erected the bastions and the walls (now almost entirely destroyed) to defend themselves from the probable aggressions of the people of Albenga, and from the Saracens who infested our seas. They had not yet finished this splendid work when Aliamath took and burnt the neigbouring town of Laigneglia, which however he was soon obliged to abandon, Giutliano Berno, of 
- Alassio having sailed to meet him, and defeated and put him to flight.

In this century (1500) new evidences appear of the working in coral. In $\mathbf{1 5 9 5}$ on $8^{\text {th }}$ September fifteen hundred Alassians went to Vico of Mondovì to honour the Madonna of that Sanctuary; they offered 60 ducats and a crucifix with a rock of coral finely carved. At the end of 1593 they built the convent of the Capuchins at the Coscia, and rebuilt the rustic Sanctuary of Nostra Signora della Neve in 1579.

The year 1600 appears full of praiseworthy works of genius, and ornamental arts practised by the Alassians; clever writers became celebrated, the first of whom was Giancardi with his History of Alassio (1653), then the lawyer Alessandro Ferrari, Giovanni Battista de Cutis, Alessandro Battaglia, and the patriotic Gian Maria Bonorino.

Theological science was cultivated with great success by Tommaso Gastaldi, whose treatise (De Angelis) was the cause of his being raised to the bishopric, a position to which another Alassian, Stefano Martini 
had already been elected. For the sake of brevity I omit naming many other illustrious men of science belonging to Alassio, and come to feats of arms.

Capitain Oreglia who signalized himself in the battle of 1672 against the Savoyards in the valley of Albenga, comes first. The Genoese Republic rewarded him with a rich crown of gold, and with a special medal on which the motto: «Proemium virtutis was inscribed ». Not less worthy was captain Eligio Miralta who, with a brigantine assaulted the pirates in the Sicilian sea, defeated them and captured 40 corsairs. The Republic made him an officer of the Navy.

Erasmo simone who had fallen into the hands of the Turks, by a bold effort saved himself and his crew, and landing at Malta was made an officer of the order which takes its name from the island.

But to mention all the celebrated events would lengthen this brief account far too much; and we therefore pass on, and note that in this century (1619) the Alassians founded the convent of Sant'Andrea called 
now Santa Chiara; Giuseppe Alciato left a legacy to the parish church of 3166 francs, and Giov. Ambrogio founded the schools with his large inheritance. - Pietro Bogliolo built the church of San Fabiano and San Sebastiano in his village of Moglio which was afterwards raised to the dignity of a parish church. The coral fishers founded the church of Sant'Erasmo with their offerings, and in 1620 the Alassians restored the tottering Sanctuary of San Bernardo. Such deeds of magnificent generosity should be recorded with praise, as they made illustrious not only the persons who performed them, but also the city of their birth. - With regard to politics the fatal struggle with the people of Albenga recommenced in 1689, but Albenga had again the worst of it; and as to public administration, the Podestà and the Consiglio minore ruled the Commune, and on great occasions the general parliament of the heads of families gave the final decisions.

And now we come to the fatal $18^{\text {th }}$ century, at the beginning of which the Alas- 
sians were still very flourishing in commerca and navigation, and before 1780 more than seventy brigantines made voyages for the trade of their country. But at the outbreak of the French Revolution trade and navigation diminished gradually until they were completely destroyed by the English. The breath of liberty, and a new order of things made themselves felt in Liguria, and with the enthusiasm produced thereby, Alassio and Albenga made peace in the name of the universal brotherhood, but it was of short duration. - In the meantime the ancient confraternity of Santa Caterina was obliged to give up to the invading French doctrines its penal and civil jurisdiction over its members, but notwithstanding the new current of ideas the Alassians remained faithful to Catholic principles, and built the church of Sant'Anna in Barusso, and enlarged the church of the Capuchins, as well as the old Hospital, annexed to the church of La Carità and Vittorio Durante gave his inheritance for the benefit of the schools (a. 1796). It was at last owing to the French 
doctrines, and to the new law of the Genoese Senate by which every parish that counted nine hundred souls could form itsolf into a Commune, that in the year 1798 Moglio separated itself from Alassio and created its own Syndics, or Mayors, in the persons of Giov. Battista Porcella, Francesco and Domenico Bogliolo. But, like the laws of this epoch this new Commune shortly disappeared and Moglio was reunited with Alassio.

Many heroic actions were performed in Alassio during the frequent wars. Thus, Giuseppe Morteo saves and takes back from the Corsairs the ship and crew of Agostino Forcheri. The Marquis Onorato Ferreri by his influence saves Alassio from entire destruction, obliging the English to throw into the sea the ammunition with which they intended to blow it up. Emmanuele Giraldi offers himself to slavery in the place of his father, and the Alassians having made a subscription released this generous man. Giacomo Mainetto who, went round the world in a small polacca. (1785), Pietro Ravaglio, Pasquale Fontana, and 
many others should be mentioned, but the brevity of this historical account hinders us from doing so. 'Ihus towards the end of this century in spite of the sworn peace and the new brotherhood, this smothered strife between Albenga and Alassio recommenced in 1790, and Albenga entered into treaties to. sell Alassio. Naturally the Alassians revolted, and a decree of Napoleon I finally put an end to the longstanding contest.

The $19^{\mathrm{TH}}$ CENTuRy. - The campaign of Italy, fought partly in Liguria, did much injury to the Alassians, and first of all, in 1800 the Austrians dismantled the bastions, and carried away the cannons. Shortly after the Genoese Republic underwent political changes, and became the Ligurian Republic, and Alassio formed a Canton with Albenga as head of the district.:In 1802 Albenga lost its title of chief province, and was made the same as Alassio, the latter remaining a Canton which included the valley of Stellanello and Testico. But the Ligurian Republic, whilst it enlarged the Canton deprived it of its ancient privilege 
of writing on unstamped paper. This state of things continued until the annexation of the Ligurian Republic to the French Empire (1805).

In 1805 the Canton of Alassio, as well as all the ex-Ligurian Republic, was placed under the new French tributary system. With the abdication of Napoleon I (1814), Liguria was assigned to the Kingdom of Sardinia at the Congress of Vienna. The Sardinian King having returned to his new states, restored the ancient regimen, taking from Alassio Stellanello and Testico; but in the hurry of returning to the ancient state of things, forgot the tributary system. In 1815 the abbey of Santa Maria and San Martino della Gallinara was restored, and Monsignor Biale, bishop of Albenga was placed at the head of it. It is to be remarked that from 1473 this abbey was conceded as a Commenda, and the last abbot named, was Father Giustiniani in 1795 .

From 1815 until now, nothing remarkable has occurred. Alassio contributed to the number of those who fell for the in- 
dependence of Italy, but Modern History . being still subject to the lively impressions of recent events, cannot by written with impartiality and therefore our account must stop here.

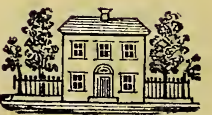


FIOIA 
I beg the more advanced botanist to be indulgent to my descriptions, which are intended only for beginners, and were made at a time when I was myself making my first attempts. 


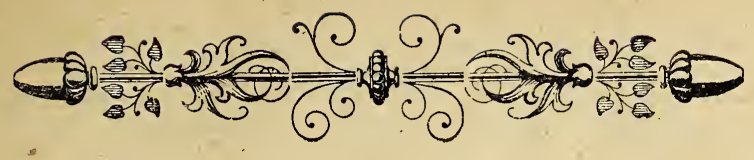

Stembergia lutea (GAWL).

(Nat. Ord. Amaryllidaceae)

Amaryllis lutea, Linnaeus, Allioni.

Leaves of an intense green, 2-3 decimetres long by about 2 centimetres wide, a little curved toward the ground, with surfaces not quite smooth but lined by numerous parallel minute veins, and with a central longitudinal channelling convex in the inferior page so as to resemble at first sight a mid-rib. The leaves ai their base embrace the stalk below which is a bulb.

Scape a little shorter than leaves with an unique large hermaphrodite flower of 
a bəautiful golden colour. Height of the flowers from the top of the scape about 7 centim., braadth never reaching to 4 centim. Spathe surrounding the ovary, whitish, about 3 centim. long.

Perigone campanulate, without crown, with a short funnel-shaped tube, and with six oblong or obovate divisions.

Stamens 6, inserted one into each segment of the perigone; long filaments; anthers turned inwards, inserted upon the stamen at the middle of the bend.

Stigma with three lobes; style 1, nearly as long as the segments of the perigone.

Ovary 3 celled, ovate, indehiscent, fleshy when it is still green.

Flowers in the autumn, especially in September, and October. I gathered some specimens in the uncultivated grounds of Vegliasco on the $15^{\text {th }}$ Octobər 1887. It is not very common, and grows well in the gardens.

Has emstic and narcotic properties and it is somewhat poisonous. 


\section{Pancratium maritimum (Linnaeus).}

(Nat. Ord. Amaryllidaceae)

Scape of 2-4 decim., round, smooth, entering deeply into the sand where it reaches the bulb which sometimes is as large as a lemon, and has the same medical properties as Scilla Maritima, L., viz. diuretic. The external parts are glaucous, the parts covered with sand are white.

Leaves fleshy, sword-shaped, about $1 \frac{1}{2}$ centim. wide, by 3 decim. long, a little twisted, and bent towards the ground, concave in the upper page, convex in the lower, of the same colour in all the exposed part. When broken a viscous juice issues. They are fairly tough: their thickness a little more than 1 millim. at the axis, and diminishes towards the edges.

Flowers white, in a terminal umbel, from three to twelve, giving a strong perfume like the lily which it resembles in shape and size.

Scarious spathe, 2-valved, surrounds the flowers at their insertion in the stem.

The perigone has six divisions linear- 
lanceolate, acute; the tube of the perigone longer than the limb, or the campanulate part of the corolla, named crown; filaments of the stamens connected for a good distance with the crown. The anthers are linear, curved, inserted by the concave part on the stamens which are 6 in number; style 1 , very long, filiform, with only 1 white stigma, 3-lobed.

Capsule globular, obovate, 3-angled, the size of a walnut, and 3-loculicidal-valves with many black seeds, compressed, unequal, very numerous, smooth and shining.

Flowers from July to September, but in the beginning of October it is possible to find some specimens still in blossom: numerous Convolvulus Hawkmoths in the evening fly from one flower to another in search of honey. During the winter the leaves may still be seen, as all do not die, indicating the place where a plant may be found. Nearly every winter the English people dig up many bulbs to send to England where they enjoy an artificial life, if they live at all. 


\section{Cakile maritima (SCOPOLI).}

(Nat. Ord. Cruciferae)

Bunias CaKile, Limnaeus; CRambe MaRItima, Allioni; Cakile litoralis, Jordan, Arduini.

A flexuous plant which grows in thick clumps, the lower part lying on the sand, about 3 or 4 decimetres high and 5 or more wide. The young twigs are herbaceous, upright, fleshy, sometimes with thin raised longitudinal lines; the old branches. are of a parched yellow colour spotted with black, and the medullary cavity filled with a blackish substance.

Fleshy leaves, 3 to 6 centim. long, alternate, deeply-lobed, split in unequal linear segments which are distant, for the most part nearly opposite, and with secondary notches. Oblong and linear leaves are rare. The petiole is long, fleshy, rounded, and grooved on the upper part.

Flowers in corymb, pale lilac; six stamens, two of which are shorter; stigma entire, without style. Four petals nearly round with long whitish petiole surrounded 
by the sepals, also four in number, the two opposite ones being smaller than the two others.

Siliqua indehiscent, of two joints, the upper quadrangular, the lower with two lateral excrescences giving the fruit nearly the appearance of a halbert two or more centimetres long. The peduncle, if pulled off, takes with it part of the bark and of the siem.

Seeds, one in each cell, shaped like a cone, with one edge more convex; the lower seed suspended from its upper tip, the seed in the upper cell attached by its lower tip to the partition between the two cells so as to be opposite in their insertion.

It flowers nearly all the year but more especially in autumn till the middle of winter and in spring.

Very abundant in all the gulf along the shore.

Properties. - Antiscorbutic, stimulating, like many of the cruciferae; it is not used in medicine. 


\section{Cakile maritima var. latifolia (POIRET)}

Very similar to the preceding, like which it is abundant, differing only in the leaves that are somewhat more fleshy, entire or scarcely dentated or sinuated, obovate ovate, oblong, and with a long petiole.

The width of the largest leaves about 3 centim., sometimes a little more.

It is to be found mixed with the Cakile maritima, the Eryngium, the Pancratium, the Medicago, etc., and like the former is easily recognized.

Anthyllis barbarjovis (LINNAEUS).

(Nat. Ord. Leguminosae)

Shrub from 5 to $\mathbf{1 6}$ decim. high, with brown. erect, hard, woody, tough stems; the flowering branches silky and with very numerous leaves growing more closely 
tôwards the end. Leaves about 5 centimetres long, at the most, imparipinnate, slightly sheathed at the base, with 4-9 pairs of sometimes opposite, sometimes alternate leaflets nearly all equal in length oblong or elliptical, concave on the upper surface, convex and careened on the lower, about one centim. long, green above, tomentose, silky, and silvery beneath.

Flowers pale-yellow in compact axillary or terminal heads, the latter placed two by two in pairs; the corolla is still attached when dry to the ripe fruit.

Calyx tomentose with 5 teeth shorter than the tube, attached to the fruit and as long as it while it is unripe, but shorter and cracked in many places when the fruit has arrived at full maturity.

Pod oval, nearly heartshaped, small, about three millim. in length; seed unique, reniform, enclosed in a horny capsule nearly as thick as a delicate finger nail.

Very abundant on the side of Capo Santa Croce, near the carriage road, and below it down to the sea, in cracks and on ledges of the cliffs. 
Flowers in April and May; its fruit reaches perfect maturity in July.

\section{Alyssum maritimum (LAMARK).}

(Nat. Ord. Cruciferae).

Clypeola maritima (Linnaeus).

A plant more or less tomentose, branching at the base, with branches erect or prostrate-ascendent from one to two decim. in length, and less than two millim. in diameter, not very thick. It covers at times a large extent of uncultivated ground, giving a peculiar odour, very similar to that of honey.

Leaves linear, entire, upright, or curved, alternate, oblong or speculated, about two centim. long, covered with a downy nap nearly imperceptible in some of the plants, in others so marked as to give a silvery appearance to the whole plant. 
Flowers small, white, in corymb; sepals 4, frail, green or reddish; petals 4 white, orbicular. Stamens 6 , two shorter than the others.

Small elliptical siliques, upright, the size of a millet seed, the upper end terminating in a fine point, edges not always equal, the faces slightly convex. Centre division transparent and silvery, dividing the siliques in two cavities, each containing one seed obovate, attached at the smaller end to the fore part of the division.

Flowers all the year, is very abundant on the beach up to a certain height.

\section{Teucrium fruticans (Linnaeus).}

(Nat. Ord. Labiatae)

Bush-like plant that on Cape Mele, the only place in the Alassian gulf in which it has been found, grows to the height of 5 to 7 decim., which perhaps it might 
exceed if the sheep who graze on Cape Mele as on our mountains did not injure the plants. It has a greenish white appearance very like bushes of wild olives, with young twigs tetragonal, white-tomentose.

Leaves opposite, entire, oblong, lanceolate, sessile, white-tomentose beneath, with small prominent nervures; above they are of bright green covered with dust. Those of the young shoots reach 3 centim. in length by 8 millim. in width, but those of the remainder of the plant are much smaller, their average length being 1 cent. or a little more.

Flowers axillary opposite each other like the leaves, of a fine violet with reticulated veins of a more intense colour. The lower lip is very long, rather concave, horizontal, with two small lateral laciniae turned forwards, and the centre one obovate or elliptic, of more than one cent. in length. The upper lip is of a slighter colour, minutely reticulated, with tiny veins, and split to the bottom.

The stamens are 4 in number, rising with the style in one mass, arched with 
a concavity towards the end of the lower lip. The style is equal to the stamens, bifid at the end.

Calyx large, funnel-shaped, penta-dentated, white-tomentose outside, green inside, with equal, pointed teeth. Peduncle a little shorter than the calyx.

Before the flowers open they look like . small whitish globes, the lower lip being wrapped over itself, and embraced by the two sections of the upper.

The fruit is a reticulated akenium, the involucrum globular, reticulated, having several dark seeds rather long.

It flowers all the year except in summer.

It is to be found on the southern slope of Cape Mele, at the side of the high road, 250 metres from the Lighthouse, and on varions part of the same slope. 
Brassica balearica (BADARÒ).

(Nat. Ord. Cruciferae)

Brassica robertiana, Gay, Arduini.

A variety of cabbage, grows from 4 to 15 decim. high, with a stem which reaches sometimes to 3 centim. in diameter, longbranched or not. Glabrous in all its parts and inclined to sea-green.

Leaves of the most robust specimens as large as those of a well grown cabbage, but generally smaller and very similar to those of common broccolo, rather fleshy, the upper ones stem-clasping oblong or lanceolate, some hastate, more or less toothed, not auriculated, the lower petiolate, lyrate, sinuated, waved, with two or more leafy projections towards the base irregularly sisattered.

Flowers, in corymb at first, large, pale yellow. Sepals four, long, oval, or elliptical; petals as long again as the sepals, obovate, with long peduncle, erect; stamens rather longer than the sepals.

Siliqua cylindrical, rather flattened per- 
pendicularly, rarely quadrangular, upright, or with one or two slight curves, and small swellings scarcely perceptible corresponding to the seeds, reticulated on the surface when quite dry. Beak conical, about 1 centim. long, at the base of the same size as the siliqua, and terminating in a point surmounted by a very small disc.

Seeds very black and suspended to the septum, one series in each of the two cavities in which the siliqua is divided; surface so little rough as to look quite smooth.

Flowers in March, April and May.

It grows. on the rocks on Capo Santa Croce, especially beyond the bridges, in, all the rocky places about Sant Anna, and on Capo Mele, at no great distance from the sea. Even in February some specimens may be found in flower. 


\section{Medicago marina (Linnaeus).}

(Nat. Ord. Leguminosae)

MEDICAGo CORDATA, Lamark.

A white-tomentose plant, from 1 to 3 decim. long, entirely trailing on the sand branching at the base, with a long slender root of the same size as the largest branches which rarely exceed the thickeness of a knitting needle.

Leaves alternate, stalked, trifoliate; leaflets entire or imperceptibly toothed on the upper edge, obovate, cuneated, the two lateral sessile on the chief petiole, the centre one with a very short petiole which is on the continuation of the chief. Length of the stalk about the half of a leaflet; stipulas entire, ciliated.

Flowers yellow, from 6 to 10 in number supported by an axillary. peduncle of about 1 centim. in length; wings equal or scarcely passing the keel. Keel split very slightly at the apex; very short pedicels; flowers in corymb. Calyx 5 -toothed in very pointed divisions. 
Legume woolly, flatter at the base than at the point, diameter of a little. more than $\frac{1}{2}$ centim., less in height than in width, spirally twisted, dextrorsum with two to four turns, edge obtuse furnished with a few points nearly covered by the down that covers the rest of the plant, and gives it a particular appearance. It is tolerably ease to take off the edge of the legume which contains the thorns, making a thread of about 6 centim. long.

Seeds 6, kidney-shaped.

Abundant on the sands; flowers from March to June.

Medicago litoralis (RHODE).

(Nat. Ord. Leguminosae)

The trunk is thinner than the preceding, but more compact, stronger and longer 2-4 decim., springs from the root, also slighter and longer, in all directions like so many rays spread on the sand. It has not a tomentose look. 
Leaves alternate, more distant from one another than in the last named plant; three leaflets dentated on upper edge, covered with very fine down more abundant in the upper part, obovate, some obovate coned, or inversely heart-shaped; the lateral leaflets with very short pedicle, the centre one with longer. Stipulas lanceolate, toothed on outer margin with a slight lengthening at the base extending beyond the insertion on the trunk.

Flowers yellow, rather smaller than those of the Medicago marina, 3-4 per peduncle; keel longer than the wings, with very slight upper indentation; footstalk aristate, longer than the leaves. Calyx 5-toothed, with very harp points.

Legume glabrous, nearly cylindrical, fat at the two extremities, dextrorsum in all the specimens examined by me. Four, seldom five turns, prickles divaricated slightly curved. Seeds 4-5, kidney-shaped.

Flowers in April, May and June.

Abundant especially on the beach, mixed with the Medicago marina. 


\section{Asphodelus fistulosus (LinnaEus).}

(Nat. Ord. Liliaceae)

Small clumps from 3 to 5 decim. high and from 2 to 4 wide, resembling those of the bulrush in the form of its leaves which rise straight from the ground, round, acuminated like so many quills of a porcupine.

Scape upright single or with branches at the top, higher than the leaves, rather larger at the base than a penholder. Roots numerous, in a bundle, entangled, wavy, rather fleshy and vertical.

Leaves flattened and clasping at the joint, all springing from the root, cylindrical or nearly so in the rest of their length, terminating gradually in a fine point, hollow inside.

Flowers white in a long raceme, more compact before flowering, resembling the flowering top of Asparagus, with inferior bracts equal to the peduncles. Petals 6, white or slightly tinged with pink, with a red-greenish stripe on the back, elliptical; Stamens 6 (three of which are shorter than 
the others), and have enlarged filaments hairy at the base, covering the ovarium.

Capsula globular, less than 4 millim. wide, 3 -valved, with cross grooves. Seeds black, from 3 to 6 , 3-sided, with grooves on the exterior surface corresponding to those of the capsule, and with about 3 small indentations on the other 2 sides.

Flowers during all the winter.

The places where it most abounds are rubbish heaps at the mouth of the tunnel at the beginning of Capo Santa Croce; along the high road which leads to Albenga and expecially at the turn near the stone quarry; along the edge of the railroad where it is more scattered. I have not yet found here the Asphodelus alBus which is rather abundant in Monte Galè, and Pizzo d’Evigno at Stellanello. 


\section{Senecio cineraria (DECANDOLLe).} (Nat. Ord. Compositae)

Cineraria maritima, Linnaeus, Allioni.

A beautiful plant to be admired on the bare rocks of Capo Santa Croce, Porto Salvo, Capo Mele, a few metres from the sea to the height of a hundred. It forms fine bushes of 60 centim. in height by 30 to 40 in width. From the root spring many erect branches woody at the base, with numerous ramifications at the top bearing the flowers. It is impossible to mistake this plant for another, even when it is not in blossom, the pure white of nearly all its parts striking the eye at the first glance.

The leaves are alternate; the lower oval, dentated, or slightly pinnatifid, with wide limb; the upper pinnato-lobated, neárly pinnatifid, woolly, very white below, specially in the young leaves, green above, and covered with a woolly substance which can be ensily removed by a slight rub, leaving the leaf glabrous and shining. The white stratum of the other parts is more 
adhesive. The secondary segments of the leaves have 2-3-4 small divisions. Average length of the leaf 7 centim., but it sometimes reaches 10 centim.

Flowers in compound corymb, 10-20 and more for each principal peduncle; lower sprays reaching with their flowers nearly always to the level of the upper ones, so that it might be said that all the compound corymbs of each principal peduncle form a large single corymb for each stem. Involucrum cylindrical with numerous sharp teeth in the edge, resulting (the involucrum) from the union of very numerous acuminated sepqls. Corolla golden-yellow, tubular, 5-toothed in the small flowers of the centre, with ovate or obovate and not very long linguetta in those of the periphery. A circular pappus of very fine hairs at half a millimetre from the receptacle surrounds th 3 corolla of each small flower. Akenia glabrous.

Senecio is derived from senex, old, either from the form of the receptacle which resembles a bald hend when the flowers are taken from it, or from the white hairs 
of the pappus which resemble gray hair.

Flowers from the middle of May till July. Some leaves remain attached to the plant all the winter.

\section{Coris monspeliensis (LinnaEus).}

(Nat. Ord. Primulaceae)

Very small clumps about 2 decim. wide, lying on the ground at the base with small stems prostrate ascending, branching at their base, thin, woody, tough, in the terminal part being of a rose-garnet colour or greenish.

Leaves linear, very numerous, sessile, coriaceous, from 1 to $1 \frac{1}{2}$ centim. long, inserted in the length of the young twigs, and curved the greater part downwards, the upper ones often marked with small sharp dentations.

Flowers violet or bluish in a dense terminal raceme of $3-5$ centim. long, by $1 \frac{1}{2}$ in diameter; bisexual and regular. The calyx is attached round the central axis 
by so short a pedicle as to seem sessile, campanulate, externally. with 11-12 and more prickly points of various lengths, and 5 triangular divisions with a yellowish linear spot in the middle, which springing from the edge of the circumference converge in a central point thus closing the campanulate cavity completely, or opening only enough to allow the tube of the corolla to pass.

Corolla hypogynous, irregular, tubular; limb dividedinto 2 lobes, the upper one larger, trifid; the lower bifid; each of these 5 little divisions slit in half for a short distance. Stamens 5, inserted in the tube of the corolla; anthers orange coloured; style very thin, stigma undivided and attaining to the same height as the anthers.

Capsula globular, opening by 5 simple valves and with one cell containing 5 ovules (seeds) imbedded in the placenta.

Flowers in April, May, June.

To be found among the rocks of Santa Croce, of Porto Salvo, and in many other arid places. 


\section{Eryngium maritimum (LinNAEUS).}

(Nat. Ord. Umbelliferae)

Plant glaucous, forming numerous bushes on the sand from Alassio to Laigueglia. Its trunk is large ( 1 cent.) in proportion to its length (4-6 decim.), erect; the root is stoloniferous and juicy.

Leaves nearly like fans, deeply undulated, Iobated, largely toothed on the edge, and with a sharp thorn terminating each indentation of the leaf. The lower leaves have a long stalk, the upper ones are sessile and half clasping the stem. Edge of the leaves slightly folded inwards, hard, leathery, and white like all the nervures which are very marked on both sides and spring from the extremity of the stalk.

From the axilla of each sessile leaf arises a long peduncle supporting a flower head, or dividing into 2-3-4 secondary peduncles with one terminal head for each. At the ead of the primary peduncle there are 2, generally 3 small leaves with 3 indentations; the 2 or 3 lateral peduncles and the central or terminal have a terminal 
flower head surrounded by an involucrum of 4-5, rarely 6 subtrilobate, patent small leaves with very sharp thorns.

Flower's head globular, of a bluish-white tint; flowers sessile oblong accompanied by a small 3 -toothed bract longer than the flower; the 5 teeth of the calyx are linear, prickly. Petals 5, white; inflex opposite to the sepals, and embracing in their fold the anther which is linear, vertical and has a groove in which the staminiterous filament passes, rises, and then bends to insert itself in the middle of the anther. Columella divided in two, attached to the achenes.

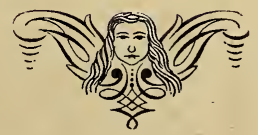


$-y$

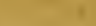




\section{ALPHABETICAL INDEX}

OF THE PLANTS FOUND BY THE AUTHOR

IN THE GULF OF ALASSIO. 


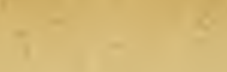


It was my intention at first to give a full account of all the plants found around Alassio, with a separate description of each; but whether it was that it required too much time, or because it would have been difficult to express my meaning in a foreign language with scientific propriety, or in fine, because it was unnecessary, since any lover of Botany can read the description in some of the books already published on the subject, I have thought it better to confine myself to giving in alphabetical order the name only of the plant, the order to which it belongs, its synonyms, the time and places in which it flourishes, with a few other particulars added for some of them. Tho student will thus be enabled, I hope, to search for a plant while it is in bloom, and to read the description in other botanical works, so as to be able to recognise them and arrange them in his herbarium.

The number of the specimens collected is considerable for so small an area but, no doubt, many kinds are still wanting, which, as I shall find them, from time to time I shall insert into my manuscript with the intention of ultimately completing the Flora of this fringe of land so highly favoured by nature. 
(1.

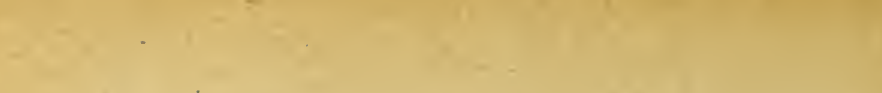

and

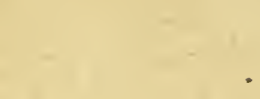

$+$

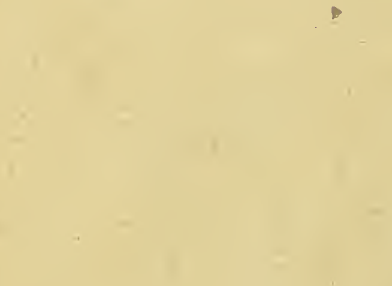

-
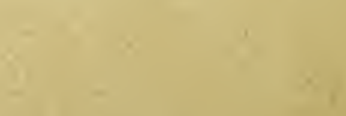


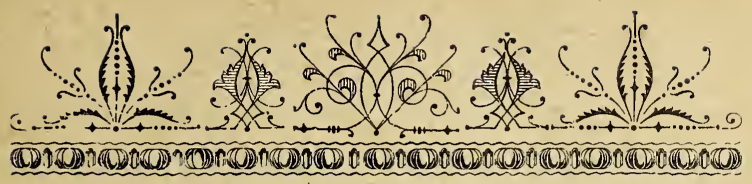

\section{AUTHORS}

Ad. = Adanson

Ait. = Aiton

All. = Allioni

Ard. = Arduini

Arch. = Archangeli

B. et $\mathrm{T} .=$ Baillet et

Timbal

Bad. = Badarò

Balb. = Balbis

Bartl. = Bartling

Bell. = Bellardi

Bth. = Bentham

Bert. = Bertoloni

Betz. = Betzius

Boiss. = Boissier .

Bonap. Ch. = Bonaparte Charles
Br. R. = Brown Robert

Cam. = Cambessedes Cass. = Cassini

Ch. = Chaix

Cham. = Chamisso

Chav. = Chavannes

C. et G. $=$ Cosson et

Germain.

Cr. $=$ Crantz

Cuss. = Cusson

Cyr. = Cyrillo

DB. $=$ De Brébisson

Dec. $=$ Decaisne

DC. $=$ De Candolle

Dc. Alph. = Decandolle Alphonse 
Desf. = Desfontianes

Desm. = Desmoulins

Desp. $=$ Desportes

Desv. = Desvaux

D. Nrs. = De Notaris

DP. $=$ De Pouzolz

Dill. $=$ Dillenius

Dorth.=Dorthres

L. D. = Léon Dufour

Dufr. = Dufresne

Forsk. = Forskàhl

Fres. = Fresenius

Fr. = Fries

G. D. = Georges Don

Gaert. = Gaertner

Gaud. = Gaudin

Gil. = Gilibert

Gir. = Girard

Gm. = Gmelin

Godr. = Godron

Good. = Goodnough

Gr. = Grenier

Gr. et Godr. = Gre-

nier et Godron

Gris. = Griszbach

Guss. $=$ Gussone

Haw. = Haworth

Hoff: = Hoffmann

Huds. = Hudson

Huss. = Hussenot
Jacq: = Jacquin

Jord. = Jordan

Juss. = Jussieu

Kit. = Kitaibel

K. = Kock

Lag. = Lagasca

Lam. = Lamarck

Lap. = Lapeyrouse

L. et L. = Lecoq et Lamothe

Lej. = Lojeune

Le Gall = Le Gall

Less. = Lessing

Lindl. = Lindlry

Lk. = Link

L. = Linné

Lob. = Lobel

Loefl. = Loefling.

Lois. = Loiseleur

M. = Mertens

M. et K. $=$ Mertens et Kock

Mich. = Micheli

Mill. = Miller

Moench $=$ Moench

Mogg. = Moggridge

Monn. = Monnier

Moric. = Moricand

Naəg. = Naegeli

Pall. = Pallas 
Parl. = Parlatore

P. B. = Palisot de Beauvois

Pers. = Persoon

Poir. = Poiret

P. et T. = Poiteau et Turpin

Poll. = Pollich

Pour. = Pou rét

Rchb. = Reichenbach

Retz. = Retzius

Reut. = Reuter

Rich. = Richard

Rob. Ch. = Charles Robin

Roem. = Roemer Roem.et Sch. = Roemer et Schultz

Salisb. = Salisbury

Salzm. = Salzmann

Schm. = Schmit

Schrad. = Schrader.

Schreb. = Schreber

Scop. = Scopoli

Sibth. = Sibthorp

Sm. = Smith

Tar. = Targioni

T. T. = Targioni Tozzetti

Ten. = Tenore

Timb. = Timbal La-

\section{grave}

T. = Tournefort

vill. = Villars

Viv. = Viviani

Wahlen. = Wahlenberg

Wald. = Waldstein

Wald. et K. = Wald-

stein et Kitaibel

Wallr. = Wallroth

Wall. = Walpers

W. et $\mathrm{N} .=$ Weihe et

Nees

Wim. = Wimmer

With. = Withering

Wulf. = Wulfen

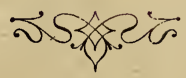




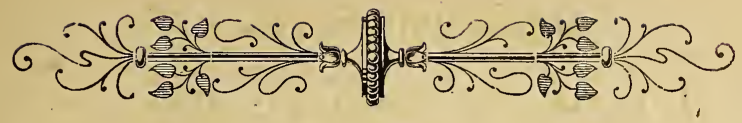

\section{CATALOGUE}

Aceras anthropophora, R. BR. - Nat. Ord. Orchidaceae. Synon. Orchis anthropophora, AlL. - Ophrys anthropophora, L. Reg. Gonghe $26^{\text {th }}$ May 1891.

ACERAS LONGIBRaCteata, Rchb. - V . Barlia longibracteata, PARL.

ACERAS PYRAMIDALIS, RCHB. - V. Anacamptis pyramidalis, RicH.

Achillea ligustica, ALL. - Nat. Ord. Compositae. Syn. Achillea sicula, RAF. June, August. Monte Bignone.

Adianthum Capillus-Veneris, L. Nat. Ord. Polypodiaceae. Commonly called Capelvenere. 
It is found in abundance all the year in the walls of wells, and on rocks which are constantly wet.

Summer.

Adonis flammea, JACQ. - Nat. Ord. Ranunculaceae. Syn. Adonis aestivalis, DC.; Adonis anomala, WALLR.

Under the olives, not very cummon. June.

Aegilops ovata, L. - Nat. Ord. Graminaceae. Syn. Triticum ovatum, Gr. et GODR.

Specimen found in April on the Capo Santa Croce, just after passing the bridges, beside the carriage road.

Agave americana, L. - Nat. Ord. Amaryllidaceae.

At Alassio it is cultivated for ornamental purposes and only by accident some samples are found here and there which have escaped from gardens.

It is very abundant at Albenga where it is employed to form impervious hedges.

Agrimonia Eupatoria, L. - Nat. Ord. Rosaceae.

Specimen gathered the eleventh of June 1888 on the road near to the church of 
Loreto. Frequent in uncultivated places: flowers from April to October.

Agropyrum junceum, P. B. - Nat. Ord. Graminaceae.

On the sands: from June to September.

Agropryrum repens, P. B. - Nat. Ord. Graminaceae. Syn. Triticum repens, L. Vulgo Gramigna; very common; May, June.

Agrostemma Flos-Jovis, L. - V. Lychnis flos-Jovis, LaM.

Agrostemma Githago, L. - V. Lychnis Githago, Lam.

Agrostis miliacea, L. - V. Milium multiflorum, CAv.

Agrostis vulgaris, WhIT. - Nat. Ord. Graminaceae.

In cultivated places: summer and autumn.

Ajax pseudo-narcissus, Haw. - Nat. Ord. Amaryllidaceae. Syn. Narcissus pseudo-narcissus, L.; Narcissus bicolor, LAP.; Narcissus festalis, SALisb.; Narcissus major, LoIs.; Narcissus radians, LaP.; Narcissus sexangularis, Roem. 
Reg. Schiff, near Villa Pozzoli; March, April.

Ajax pseudo-narcissus duplex. It is a variety of the preceding and it is found together with it at San Bernardo in one olive terrace below the Villa Bonavia. I named it duplex because I don't know what name it has, having never seen any description of it. It lives also at $A \dot{n}$ dora below Caserma dei carabinieri.

March, April.

Aiuga Iva, Schreb. - Nat. Ord. Labiatae. Syn. Teucrium Iva, L.

In uncultivated places: April, June, and autumn.

Aiuga reptans, L. - Nat. Ord. Labiatae.

Specimen found the $27^{\text {th }}$ of April in the olive plantations near the church of Loreto. Flowers from April to May.

Alga marina, Lam. - V. Posidonia caulini, KöN.

Alisma plantago var. lanceolatum, RchB. - Nat. Ord. Alismaceae.

In the old road to Moglio, in a ditch under the tower which stands below the church; 14 $14^{\text {th }}$ June 1888.

Flowers from May to July. 
Alisma ranunculoides, L. - Nat. Ord. Alismaceae.

In the bed of torrents from April to June.

Allium neapolitanum, CYR. - Nat. Ord.

Liliaceae.

Very abundant in the olive groves, it is an article of sale in the spring, being a flower which lasts a long time. Flowers in April, May, June.

Allium pulchellum, G. D. - Nat. Ord. Liliaceae. Syn. A. valdensium, Borss., Reut. Monte Pisciavino, 14 ${ }^{\text {th }}$ September 1888.

Allium roseum, L. - Nat. Ord. Liliaceae. Less abundant than the preceding and in the same localities.

Flowers from April to June.

Allium sphaerocephalon, L. - Nat. Ord. Liliaceae.

More usually found in uncultivated places; flowers are purple, in spherical umbella.

Specimen gathered in Costa Lupara the $20^{\text {th }}$ June 188s. From June to August.

Allium valdensium, Boiss. - Syn. of Allium pulchellum, G. D. 
Alnus glutinosa, Gaert. - Nat. Ord. Betulaceae. Ital. Ontano.

- It is found very seldom here, and only in the beds of torrents, while it is abundant in the territory of Albenga.

It flowers in March.

Alsine MediA, L. - V. Stellaria media, VILL

Alyssum maritimum, LAM. - Nat. Ord. Cruciferae. Syn. Clypeola maritima, L. See the full description.

Amarillys Lutea, L. - V. Sternbergia lutea, GaWL.

Amygdalus communis, L. - It is a cultivated plant; there are three or four varieties.

Amygdalus persica, L. - Cultivated plant; many varieties.

Anacamptis pyramidalis, RICH. - Nat. Ord. Orchidaceae. Aceras pyramidalis, Rснв.; Orchis pyramidalis, L.

Flowers small and rose-coloured, united in a pyramidal form. From April to the end of June in woody places throughout all the territory. 
Anacyclus radiatus, LoIs. - Nat. Ord. Compositae. Syn. Chamaemelum valentinum, All.; Anthemis valentina, L.

I gathered this specimen in the Capo Mele beside the carriage road very near to Andora. From May to August.

Plant somewhat scarce throughout Liguria, here pretty common.

Anagallis arvensis var. coerulea, LAM.

Anagallis arvensis var. phoenicea, Lam. - Nat. Ord. Primulaceae.

I gathered these two specimens under the olive groves of M.rs Gibb's villa, the $15^{\text {th }}$ May 1888.

Flowers from April to July.

Anchusa italica, ReTz. - Nat. Ord. Borragineae. Syn. Buglossum sempervirens, ALL.

Plant with numerous erect stems, 3-6 decim. high, branching at the top. The lower leaves petiolate, the upper sessile, all covered with stiff hairs. Flowers of intense blue. Very common.

Flowers from April to July.

Androsaemum officinale, All. - V. Hypericum androsaemum, L. 
Anemone hepatica, L. - Nat. Ord. Ranunculaceae.

Leave 3-lobed, reddish beneath, often spotted with greenish white above. Flowers numerous, usually blue.

San Bernardo, Fasce Grasse, Gonghe, Schiff, February to April.

Anemone hortensis var. stellata, L. Nat. Ord. Ranunculaceae. Syn. Anemone stellata, LAM.

Gonghe $1^{\text {st }}$ April 1888; very common at Andora, in the meadows; violet flowers. February to April.

Anemone stellata, Lam. - V. Anemone hortensis var. stellata, L. *

Anemone trifolia, L. - Nat. Ord. Ranuculaceae.

White flowers; leaves with three serrated leaflets.

In shady places of the wood at San Bernardo. March, April.

Anthemis arvensis, L. - Nat. Ord. Compositae. Syn. Anthemis nicaensis, WILLD.; Chamaemelum arvense, ALL.

In the beginning of Costa Lupara road, 
opposite the toll-booth, the $20^{\text {th }}$ June 1888 . White flowers. April to September.

Anthemis nicaensis, Willd. - V. Anthemis arvensis, L.

Anthemis valentina, L. - V. Anacyclus radiatus, LoIs.

Anthericum liliago, L. - V. Phalangium liliago, SchreB.

Anthyllis barba-Jovis, L. - Nat. Ord. Leguminosae. See the full description.

Anthyllis tetraphylla, L. - Nat. Ord. Leguminosae.

In the beginning of the Capo Santa Croce, near to the tunnel.

Very abundant in the Costa Lupara, Finarina. April, May.

Antirrhinum latifolium, DC. - Nat. Ord. Scrofulariaceae.

Leaves ovate or obovate-lanceolate; flowers yellow.

In the grounds belonging to Mrs Gibb, two or three terraces above her house, on the side of the Madonna del Vento.

From April to September. 
Antirrhinum orontium, L. - Nat. Ord. Scrofulariaceae.

Flowers of purplish-red, leaves linear, generally curved; calyx with linear divisions longer than the carolla. Very commonly under the olives. Flowers during almost all the year, expecially in the autumn and spring.

Arabis muralis, BeRT. - Nat. Ord. Cruciferae.

I gathered this plant in the torrent of Capuccini the $27^{\text {th }}$ March 1888, at about 800 metres from the estuary, on the right bank. Common in uncultivated places. April, May.

Arabis perfoliata, LAM. - Nat. Ord. Cruciferae.

Here and there in rugged places. April, May, June.

Arbutus unedo, L. - Nat. Ord. Ericaceae. Vulgo Armorin.

A bush, which hardly ever exceeds here the height of 4 metres, though around the lakes of Killarney in the county Kerry, Ireland, frequently ex- 
ceeds 15 metres in height. It is abundant in Costa d'Oreto (commonly called Raseu). In the woods on the seaward or southern side, it is rather scarce. Its red fruits greedily sought by birds are also sold in the market. September, October, November.

Arisarum vulgare, TAR. - Nat. Ord. Araceas. Syn. Arum arisarum, L., All. Vulgo Lumin, Cuchetti.

Very common in all the cultivated places in the district. It has a very bad smell greatly resembling that of the ozena: From September to March.

Aristolochia rotunda, L. - Nat. Ord. Aristolochiaceae.

In the torrent near the church of Loreto the $27^{\text {th }}$ April 1888, and in many other damp places. April, May, June.

Artemisia absinthium, L. - Nat. Ord. Compositae. Vulgo Assenzio.

Common enough in a cultivated state, but it is not found here growing wild.

ARUM arisarum, L., AlL. - V. Arisarum vulgare. 
Arum italicum, MiLL. - Nat. Ord. Araceae. Syn. Arum maculatum, ALL., B.

It is different from ARUm maculatum, L., which does not grow in our district. April, May.

Arundo Donax, L. - Nat. Ord. Graminaceae. Vulgo Canna.

Cultivated, often it reaches the height of 5 metres, and is employed in many ways. August, September.

Asclepias vincetoxicum, L. - V. Cynanchum vincetoxicum $R$. BR.

Asparagus acutifolius, L. - Nat. Ord. Asparagaceae. Syn. Asparagus Corruda, Scop.

Abundant in uncultivated places. August, September.

Asparagus Corruda, Scop. - V. Asparagus acutifolius.

Asparagus officinalis, L. - Nat. Ord. Asparageceae.

Common like the Asparagus acutifolius, and in the same places; it is also cultivated. 
Asperula arvensis, L. - Nat. Ord. Rubiaceae.

Very common, under the olive trees. May, June.

Asphodelus fistulosus, L. - Nat. Ord. Lilliaceae.

See the full description.

Asplenium adiantum nigrum, L. Nat. Ord. Polypodiaceae. Syn. Asplenium acutum, Poll.; Asplenium Virgilii, BoRY. Common in damp and shady places, beside the rivulets, etc. Spring and autumn.

Asplenium ruta muraria, L. - Nat. Ord. Polydiaceae.

Spring and autumn. North wall of the Orphanage, which was formerly the Convent of Santa Chiara.

Asplenium trichomanes, L. - Nat. Ord. Polypodiaceae. Syn. Asplenium -Petrarchae, DC.; Asplenium Vallis-clausae, REQ.

In the same places as the preceding.

Aster acris, L. - Nat. Ord. Compositae: Syn. Aster hyssopifolius, CAv.; Galatella punctata, DC. 
It covers here and there with its beautiful blue flowers considerable pieces of - uncultivated grounds, from a few metres from the sea to the top of the mountains. . Flowers from August to the end of October.

Aster dysentericus, All. - V. Pulicaria dysenterica, GAERT.

Aster hirtus, AlL. - V. Inula hirta, L.

Asteriscus spinosus, GR. et GoDR. Nat. Ord. Compositae. Syn. Buphthalmum spinosum, L.; Pallenis spinosa, Cass. - Very common. From June to August.

Atanasia maritima, L. - V. Diotis candidissima, Desf.

Atriplex halimus, L. - Nat. Ord. Chenopodiaceae.

Along the railway where it is planted . to form a hedge. July to October.

Avena sterilis, L. - Nat. Ord. Graminaceae.

- Very abundant in the olive groves. April, May. 
Ballota foetida, Lam. - V. Ballota nigra.

Ballota nigra, L., ALL. - Nat. Ord. Labiatae. Syn. Ballota foetida, LaM. Vulgo Marrobio fetido.

From June to August.

Beside the torrents and damp roads.

Barckhausia Foetida, DC. - V. Crepis foetida, L.

Barckhausia glandulosa, Presl. - V. Crepis foetida, $\mathrm{L}$.

Barckhausia zacintha, Marg. - V. Crepis foetida, L.

Barlia longibracteata, PARL. - Nat. Ord. Orchidaceae. Syn. Loroglossum longibracteatum, Moris.; Orchis longibracteata, VIv.; Orchis Robertiana, LoIs.; Aceras longibracteata, RcHB.

Villa Gonghe, and torrent of the $\mathrm{Ca}$ puchins.

January, March, April.

Bellis perennis, L. - Nat. Ord. Compositae.

Flowers almost all the year. Very common everywhere, especially in uncultivated places. 
Bellis sylvestris, CYR. - Nat. Ord. Compositae.

March, October. Nearly as common as the preceding, but almost never under olive trees.

Blitum virgatum, L. - V. Chenopodium virgatum, B. et $T$.

Bonaveria securidaca, RcHB. - Nat. Ord. Leguminosae. Syn. Coronilla securidaca, L.; Securidaca legitima, GaERT.; Securigera coronilla, DC.

In Bonifai's garden, the $23^{\text {rd }}$ July 1888. Flowers from May to July, beside the roads, and under the olive trees; it is very common.

Bonjeanea recta, Rchb. - V. Dorycnium rectum, DC.

Borrago officinalis, L. - Nat. Ord. Borraginaceae. Very common. April, July.

Brassica balearica, BAD. - Nat. Ord. Cruciferae.

See the full description. From February to May. 
Brassica Robertiana, Gay., Ard. - V. Brassica balearica, BAD.

Briza maxima, L. - Nat. Ord. Graminaceae. Syn. Briza major, PresL.; Briza monspessulana, GouaN.

April, July.

Briza minor,"L. - Nat. Ord. Graminaceae. Madonna della Guardia, from April to July.

Bromus maximus, DESF. - Nat. Ord. Graminaceae. Syn. Bromus madrilensis, DuBY.

April, July.

Brunella AlBa, Pall. - V. Brunella vulgaris var. laciniata, L., ARCH.

Brunella hyssopifolia, LAM. - Nat. Ord. Labiatae. June, September.

Brunella laciniata, L. part. All. - V. Brunella vulgaris et laciniata, L., ARCH.

Brunella vulgaris et laciniata, L. Arci. - Nat. Ord. Labiatae. Syn. Brunella alba, PAlt.; Brunclla laciniata, L. June, July.

Alassio and its Flora 
Buglossum sempervirens, All. - V. Anchusa italica, BETz.

BunIAS CAKILE, L. - V. Cakile maritima, ScOP.

Buphthalmum sPinosum, L. - V. Asteriscus spinosus, Gr. et GoDr.

Bupleurum protractum, HoFF. etLK. Nat. Ord. Umbelliferae.

Under olive trees; at first sight it is easy to take this plant for an euphorbiacea. May.

Bupleurum rotundifolium, L. - Nat. Ord. Umbelliferae.

May, June. In the olive terraces.

CAkile littoralis, JoRd., ARd. - V. Cakile maritima, ScoP.

Cakile maritima, ScoP. - Nat. Ord. Cruciferae.

See the full description.

Cakile maritima var. latifolia, PoIR. Nat. Ord. Cruciferae.

See the description. 
Calamintha officinalis, MoENCH. - Nat. Ord. Labiatae.

July, September.

Calendula arvensis, L. - Nat. Ord. Compositae. Syn. Calendula ceratosperma, VIv. Almost all the year, very common.

Calycotome spinosa, Lk. - Nat. Ord. Leguminosae. May.

Campanula macrorrhiza, GiY. - Nat. Ord. Campanulaceae. Syn. Campanula nicaensis, Risso, ARD.

Flowers almost all the year.

Campanula Mredium, L. - Nat. Ord. Campanulaceae. June, August.

Campanula rapúnculus, L. - Nat. Ord. Campanulaceae. May, September.

Campanula rotundifolia, L. - Nat. Ord. Campanulaceae. Syn. Campanula Reboudiana, Gr. et Godr. June, July.

Campanula Sabatia, D. NRs. - Nat. Ord. Campanulaceae. 
Mr. Emile Burnatt found it on the rocks of Capo Santa Croce. June.

Campanula speculum, L. - V. Specularia speculum.

Capsella bURsa pastoris. - V. Thlaspi bursa pastoris.

Cardamine pratensis, L. - Nat. Ord. Cruciferae. June, July.

Carex acuta, L. - Nat. Ord. Cyperaceae. Syn. Carex caespitosa, GaY, All., Ard.; Carex Goedenowii, Gay.

April, May, July.

Carex caespitosa, All. - V. Carex acuta, L.

Carex distans, L. - Nat. Ord. Cyperaceae. On the Torrente Barusso. April, May.

Carex divisa, Huds. - Nat. Ord. Cyperaceae. Syn. Carex cuspidata, Bert.; Carex schaenoides, Desf.; Carex splendens, Pers.

Carex flacch, Schret. - V. Carex rechrva, Huds. 
Carex Goodenowir, Gay. - V. Cares acuta, L.

Carex recurva, Huds. - Nat. Ord. Cyperaceae. Syn. Carex glauca, Scop.; Carex flacca, Schreb., ARD.

Below villa Durante, Reg. Piani. March, April, May.

Carex remota, L. - On the same place as Carex distans, L. May, July.

Carlina vulgaris, L. - Nat. Ord. Compositae.

Uncultivated ground. July, August.

Catananche caerulea, L. - Nat. Ord. Compositae. Vulgo Belvedere turchino.

Uncultivated grounds at a level of not less than 200 metres above the sea.

June, September.

Caucalis grandiflora, L. - V. Daucus grandiflorus, B. et $\mathrm{H}$.

Caucalis infesta, B. et H. - Nat. Ord. Umbelliferae. Syn. Torilis helvetica, GM.; Torilis infesta, WALLR. 
Caucalis Scandix. L. - Vulgo Pidocchi. On the olive terraces. May, June.

Caucalis maritima, All. - V. Daucus maritimus, GaerT.

Centaurea amara, L. - Nat. Ord. Compositae. Syn. Centaurea serotina, Bor. Summer, Autumn.

Centaurea Galactites, L. - V. Galactites tomentosa, Moench.

Centaurea Jacea, L. - Nat. Ord. Compositae. Syn. Centaurea parviflora, LAM. Summer, Autumn.

Centaurea pániculàtà, L. - Nat. Ord. Compositae. May, August.

Centranthus ruber, DC. - Nat. Ord. Valerianeae. Syn. Valeriana rubra, L.; Centranthus latifolius, DuFr.

Almost all the year, on the old walls of the rivers and of the olive terraces.

Ceterach officinale, W. - Nat. Ord. Polypodiaceae. Syn. Asplenium ceterach, L., AlL. Vulgo Cedracca, erba ruggine. June, October. 
Chamaemelum arvense, All. - V. Anthemis arvensis, L.

Chamaemelum Valentinum, All. - V. Anacyclus radiatus, LoIs.

Chelidonium alaucium, L. - V. Glaucium luteum, Scop.

Chelidonium majus, L. - Nat. Ord. Papaveraceae.

April, September. In the damp places of gardens.

Chenopodium Bonus Henricus, L. Nat. Ord. Chenopodiaceae. Vulgo Colubrina.

Very common; July to September.

Chenopodium murale, L. - Nat. Ord. Chenopodiaceae.

Very common, July to October.

Chenopodium virgatum, B. et H. - V. Blitum virgatum.

Chlora perfoliata, L. - Nat. Ord. Gentianaceae. Syn. Gentiana PERFoliata, Ali. June, August. 
Chondrilla juncea, L. - Nat. Ord. Compositae.

June, September.

Chrysanthemum coronarium, L. Syn. Pinardia coronaria, Less.

June, September.

Chrysanthemum Leucanthemum, L. - V . Leucanthemum vulgare, L.

Chrysanthemum segetum, L. - Nat. Ord. Compositae. July, August.

Cichorium Intẏbus, L. - Nat. Ord. Compositae. Syn. Cichorium glabratum, PresL.; Cichorium hirsutum, Gr. Vulgo Radicchio.

June, September.

Cineraria maritima, L. - Syn. V. Senecio cineraria, DC.

Cistus albidus, L. - Nat. Ord. Cistineae. May, June.

Cistus laevipes, L. - V. Helianthemum laevipes, PERs. 
Cistus monspeliensis, L. - Nat. Ord. Cistineae. Syn. Cistus florentinus, Lam. In wild places. May, June.

Cistus salvi olius, L. - Nat. Ord. Cistineade.

May, June.

Cistus tuberaria, L. - V. Helianthemum tuberaria, MiLl.

Clematis vitalba, L. - Nat. Ord. Ranunculacene. Syn. Clematis flammula, AlL. Juie, July.

Clypeola maritima, L. - V. Alyssum maritimum, LAM.

Cochlearia Draba, L. - V. Lepidium Draba, L.

Colchicum autumnale, L. - Nat. Ord. Colchicaceae. Syn. Colchicum patens, Schultz; Colchicum vernale, Hoff.

September, October.

Convolvulus altheoides, L. - Nat. Ord. Convolvulaceae.

Very common, especially on the Capo Santa Croce. April, July. 
Convolvulus arvensis, L. - Nat. Ord. Convolvulaceae.

May, August.

Convolvulus cantabrica, L. - Nat. Ord. Convolvulaceae.

May, August.

Convolvulus sepium, L. - Nat. Ord. Convolvulaceae. June, August.

Convolvulus soldanella, L. - Nat. Ord. Convolvulaceae. Common: May, June.

Conyza saxatilis, L. - V. Phagnalon saxatile, CAss.

CONYZA sORDIDA, L. - V. Phagnalon sordidum, DC.

CopUlaria VISCOSA, GR. et GodR. - V. Inula viscosa, Art.

Coriaria myrtifolia, L. - Nat. Ord. Coriarieae. Uncultivated grounds.

May. 
Coris monspeliensis, L. - Nat. Ord.

Primulaceae.

See the full description.

April, June.

Coronilla cretica, L. - Nat. Ord. Leguminosae.

Very abundant on the Capo Santa Croce.

May, June.

Coronilla emerus, L. - Nat. Ord. Leguminosae.

April, June.

Coronilla securidaca, L. - V. Bonaveria securidaca, RchB.

Coronilla scorpioides, K. - Nat. Ord. Leguminosae. May, June.

Cracca Gerardi. - V. Vicia Gerardi.

Cracca maior, Frank. - V. Vicia cracca, L.

Crambe maritima, All. - V. Cakile maritima, Scop.

Crambe Paniculata, All. - V. Neslia paniculata, Desv. 
Crataegus ozxyacantha, L. - Nat. Ord. Rosaceae. Syn. Mespilus oxyacantha, ALu.; Crataegus oxyacanthoides, TH. April, May.

Crataegus azarolus, L. - Cultivated species; red, and wite.

CRepis ECHIOIdEs, All. - V. Helminthia echioides, Gaert.

Crepis foetida. L. - Nat. Ord. Compositae. Syn. Barchkausia foetida, DC.; Barchkausia glandulosa, PREsL.; Barehkausia Zacintha, MARG. June, September.

Crepis nemausensis, Gouan. - - V. Pterotheca nemausensis, CAss.

Crepis nicaensis, BALB. - Nat. Ord. Compositae. Syn. Crepis scabra, DC. . May, June.

Crithmum maritimum, L. - Nat. Ord. Umbelliferae.

On the Capo Santa Croce, near. the, sea.

July, September. 
Crucianella angustifolia; L. - Nat. Ord. Rubiaceae.

June.

Cupullaria graveolens, Gr. et Godr. - V. Inula graveolens, Desf.

Cuscuta europaer, L. - Nat. Ord. Convolvulacane. Syn. Cuscutr major, DC.; Cuscutn epithymum, TH.; Cuscuta Schkuhriana, Pheiff.

Parasitic plant, filiform, of reddish colour, which winds itself round other plints especially the Globularia alypum which is fairly abundant on the promontory of Porto Salvo.

Juñe, Auguist.

Cynanchum vincetoxicum, BR. B. Nat. Ord. Asclepiadaceae. Syn. Asclepias vincetoxicum, L.; Vincetoxicum, officinale, MoEnch.

May, September.

Cynoglossum omphalodes, L. - V. Omphalodes vein?, Monnch.

Cynoglossum pictum, Art. - Nat. Ord. Borraginaceae. Syn. Cynoglossum creticum, Virt.

May, June. 
Cynosurus aureus, L. - V. Lamarckia aurea, MOENCH.

Cyperus aureus, Ten. - Nat. Ord. Cyperaceae. Syn. Cyperus pallidus, SAvi; Cyperus tenorii, Presl.

Very common in the beds of torrents. September, October.

Cyperus capitatus, VAND. - Nat. Ord. Cyperaceae. Syn. Galilea mucronata, PARL.; Schaenus mucronatus, L.; Cyperus schaenoides, Gris.

On the sands. April, September.

Cyperus schaenoides, Gris. - V. Cyperus capitatus.

Daphne Gnidium, L. - Nat. Ord. Daphnaceae. Syn. Thymelaea Gnidium, ALL. Woods. July, September.

Daucus carota, L. - Nat. Ord. Ombelliferae. Syn. Daucus mauritanicus, AlL; Daucus foliosus, Guss.; Daucus gibbosus, BERT.

May, December.

Daucus grandiflorus, B. et $\mathrm{H}$. - Nat. Ord. Ombelliferae. Syn. Orlaya grandi- 
flora, HoFs.; Caucalis grandiflora, L. June, August.

Daucus maritimus, GaERT. - Nat. Ord. Ombelliferae. Syn. Orlaya maritima, K.; Caucalis maritima, ALL.

Diantus Carthusianorum, L. - Nat. Ord. Caryophylleae. June, August.

Dianthus FILIFormis, LAM. - V. Gypsophila saxifraga, L.

Dianthus saxifragus, L. - V. Gypsophila saxifraga, L.

Digitalis lutea, L. - Nat. Ord. Scrofulariaceae.

In the torrent S. Bernardo. May, June.

Digitaria sanguinalis, Scop. - Nat. Ord. Graminaceae. Syn. Panicum sanguinale, L.

July, September.

Diotis candidissima, DEsF. - Nat. Ord. Compositae. Syn. Athanasia maritima, L. On the sands. May, July. 
Diplachne serotra, LK. - V. Molinia serotina, M. et $\mathrm{K}$.

Diplotaxis tenuiColia, DC. - Nat. Ord. - Cruciferae. Vulgo Ricora.

May, November.

Dipsacus sylvestris, Mill. - Nat. Ord. Dipsaccae. Syn. Dipsacus fullonum, L. June, August.

Doryonium rectum, DC. - Nat. Ord. Leguminosae. Syn. Lotus rectus, L.; Bonjeanen recta, Rchi.

In damp places, May.

Dorycnium suffruticosum, VILL. - Nat. Ord. Leguminosae. Syn. Dorycnium monspelliensum, T.; Dorycnium pentaphyllum, Rchв.; Lotus dorycnium, L.

May, June.

Echinophora spinosa, L. - Nat. Ord. Umbelliferae.

On the sands. July, Angust.

Echium vulgare, L. -- Nat. Ord. Borraginaceae. Syn. Echium pustulatum, Gr. et Godr.; Echium tuberculatum, HoFr., LK., ARD.

May, August. 
Epilobium palustre, L. - Nat. Ord. Onagrarieae.

In the bed of torrents. June and July.

EPIPACTIS ABORTIVA, ALL. - V. Limodorum abortivum, SwCH.

Equisetum arvense, L. - Nat. Ord. Equisetaceae.

In the bed of torrents. March, April.

Erica arborea, L. - Nat. Ord. Ericaceae.

Vulgo Brugo; fr. Bruyere, engl. Heath. This species and the following have a large woody portion hidden under ground forming the stem, which is commercially useful for making the so called briarroot pipes. It covers the top of almost all our mountains.

March, April.

Erica scoparia, L. - Nat. Ord. Ericaceae. Vulgo Scopa, Brugu. Woods at a higher level than the preceding.

April, May.

Erigerom canadensis, L. - Nat. Ord. Compositae. July, October. Alassio and its Flora 
ERigerom graveolens, L. - V. Inula graveolens, DEsF.

ERIGerom viscosum, L. - V. Inula viscosa, Art.

Erodium moschatum, L'HERIT. - Nat. Ord. Geraniaceae. Syn. Erodium melapoides, LoIs.; Geranium moschatum, L., Alu. April, June.

Erodium romanum, L'HERIT. - Nat. Ord. Geraniaceae. Syn. Geranium romanum, L.

April, June.

Ervum aristatum, RaF. - V. Vicia gracilis, Lors.

ERvum longifolium, Ten. - V. Vicia gracilis, LoIs.

ERvum Gracile, DC. - V. Vicia gracilis, Lors.

Ervum tetraspermum, L. - V. Vicia gemella, CR:

Eryngium campestre, L. - Nat. Ord. Umbelliferae. June, September. 
Eryngium maritimum, L. - Nat. Ord. Umbelliferae.

On the sands. June, August.

Erysimum officinale, L. - Syn. Sisymbrium officinale, Scop.

Erythraea pulchella, Fr. - Nat. Ord. Gentianaceae. Syn. Gentiana ramosissima, All.; Erythraea pyrenaica, Pers., GILlet et Magne; Erythraea ramosissima, Pers., Gillet et Magne. June, September.

Eupatorium cannabinum, L. - Nat. Ord. Corymbiferae.

Summer. In the bed of torrents.

Euphorbia amygdaloides, L. - Nat. Ord. Euphorbiaceae. Syn. Euphorbia ligulata, Chaub.

April, May.

Euphorbia baselices, Ten. - Nat. Ord. Euphorbiaceae.

Very common upwards from the level of about 100 metres.

May, July, August.

Euphorbia cyparissias, L. - Nat. Ord. Euphorbiaceae. Syn. Euphorbia esuloides, DC. 
Not very common at Alassio; here and there along the railway.

April, May.

Euphorbia dendroides, L. - Very common everywhere.

March, May.

Euphorbia dulcis, L. - Syn. Euphorbia carniolica, DC.; Euphorbia purpurata, Тн.; Euphorbia solisequa, Rснв.

April, June.

Euphorbia helioscopia, L. - April, August.

Euphorbia Paralias, L. - On the western sands of Capo Mele.

May, August.

Euphorbia peplis, L. - On the sands between Alassio and Laigueglia. July, October.

Euphorbia peplus, L. - Almost all the year.

Euphorbia pilosa, L. - Syn. Euphorbia paniculata, Lors: Euphorbia illyrica, Lois., Gillelet et MAGNe.

On damp places, not frequent. June, July. 
Euphorbia pubescens, WAHLEN. - Syn. Euphorbia pilosa, Brot.; Euphorbia pilosa, All.

June, July.

Euphorbia segetalis, L. - Syn. Euphorbia longibracteata, DC.

Very common. May, July.

Euphorbia serrata, L. - April. May.

Euphorbia spinosa, L. - Syn. Euphorbia pungens, LaM.

Capo Santa Croce near the sea, and in wild places, very common.

Ápril, June.

Euphorbia verrucosa, LAM. - Syn. Euporbia akenocarpa, Guss.; Euphorbia dulcis, SiвTH.; Euphorbia sphoerocarpa, SALZ.

May, June.

Ferula communis, L. - Nat. Ord. Umbelliferae.

Very abundant in the island Gallinara, and Capo Mele. May.

Ficaria ranunculoides, Moench. -- V. Ranunculus ficaria, L. 
Filago germanica, var. spathulata, Presl. - Nat. Ord. Compositae. Syn. Filago Jussiaei, Coss.; Filago pyramidata, Will.; Gnaphalium germanicum, AlL. June, August.

Fumana laevipes, Sp. - V. Helianthemum laevipes, Pers.

Fumana viscida var. thymifolium, SP., Mogr. - Nat. Ord. Cistineae.

March, August.

Fumaria capreolata, L. - Nat. Ord. Papaveraceae. Syn. Fumaria speciosa et pallidiflora, Jord., ARD.

February, May.

Fumaria capreolata, var. muralis, Sond. - Nat. Ord. Papaveraceae. Syn. Fumaria Petteri, Guss.

Spring.

Fumaria officinalis, L. - Nat. Ord. Papaveraceae. Vulgo Ciantagalletti.

April, September.

Galactites tomentosa, MoEnch. - Nat. Ord. Compositae. Syn. Centaurea Galactites, L.

May, August. 
Galatella Punctata, DC. - V. Aster acris,L.

Galilea mucronata. - V. Cyperus Schoenoides, Gris.

Galium Aparine, L. - Nat. Ord. Rubiaceae. Syn. Galium intermedium, Mer. April, September.

Galium saccharatum, ALL. - Nat. Ord. Rubiaceae.

May, June.

Galium tricorne, WiTT. - Nat. Ord. Rubiaceae.

$$
\text { April, May. }
$$

Galium verum, L. - Nat. Ord. Rubiaceae. Syn. Galium glabrum, REQ. May, June.

Genista germanica, L. - Nat. Ord. Leguminosae. May, June.

Genista humilis, Ten. - V. Genista tinetoria, L.

Genista marginata, Bess. - V. Genista tinctoria, L. 
Genista pilosa, L. - Nat. Ord. Leguminosae. Syn. Genista humifusa, Thore; Genista repens, Lam.

May, June.

Genista tinctoria, L. Nat. Ord. Leguminosae. Syn. Genista humilis, Ten.; Genista marginata, Bess.

June, September.

Gentiana ramosissima, All. - V. Erythrea pulchella, Fr.

Geranium dissectum, L. - Nat. Ord. Geraniaceae. May, July.

Geranium Robertianum, L. - Nat. Ord. Geraniaceae. Syn. Geranium purpureum, VILL.

March, July.

Geranium rotundifolium, L. - Nat. Ord. Geraniaceac. Syn. Geranium viscidulum, Fr.

Almost all the year.

Gladiolus palustris, GAUD. - Nat. Ord. Iridaceae. Syn. Gladiolus triphyllus, BERT. Madonna della Guardia. Nay, June. 
Gladiolus segetum, GAWL. - Nat. Ord. Iridaceae. Syn. Gladiolus 'communis, ALL. April, May.

Gladiolus triphyllus, BERT. - V. Gladiolus palustris, Gaud.

Glaucium luteum, Scop. - Nat. Ord. Papaveraceae. Syn. Glaucium flavum, CR.; Glaucium fulvum, Lors.; Chelidonium grlaucium, L.

July, August.

Globularia alypum, L. - Nat. Ord. Globularieae.

All the year, very common in arid places.

Globularia vulgaris, L. - Nat. Ord. Globularieae.

In the same places as the preceding. April, June.

Gypsophila saxifraga, L. - Nat. Ord. Caryophyleae. Syn. Dianthus saxifragus, L.; Dianthus filiformis, LAM.

Almost all the year, in wild places.

Hedysarum herbaceum, Lap. V. - Onobrychis saxatilis, ALL. 
Hedysarum saxale, L. - V. Onobrychis saxatilis, Ali.

Hedysarum supinum, CH. - V. Onobrychis saxatilis, ALL.

Helianthemum laevipes, PERs. - Nat. Ord. Cistineae. Syn. Fumana laevipes, Sp.; Cistus laevipes, L.

May, June.

Helianthemum tuberaria, MiLL. - Nat. Ord. Cistineae. Syn. Cistus tuberaria, L. June, July.

Helianthemum vulgare, GAERT. - Nat. Ord. Cistineae. Syn. Helianthemum surrejanum, MiLL.

May, June.

Helianthemum vulgare var. roseum, All. - Nat. Ord. Cistineae. May, June.

Helicrysum angustifolium, DC. - V. Helicrysum staechas, GaERT.

Helicrysum italicum, Guss. - V. Helicrysum staechas, GAERT. 
Helicrysum staechas, GAERT. - Nat. Ord. Compositae. Syn. Helicrysum angustifolium, DC.; Helicrysum italicum, Guss.

May, August.

Heliotropium europeum, L. - Nat. Ord. Borraginaceae. Almost all the year in cultivated grounds.

Helleborus faetidus, L. - Nat. Ord. Ranunculaceae.

Very common in the bed of Merula river, rare at Alassio. February, May.

Helleborus niger, L. - Nat. Ord. Ranunculaceae.

Woods of Monte Pisciavino between Villa Murchio G. and Palazzina.

November, March.

Helminthia Echioides, Gaert. - Nat. Ord. Compositae. Syn. Crepis echioides, Alu.; Picris echioides, L.

June, August.

Hieracium pilosella, L. - Nat. Ord. Compositae. Syn. Hieracium peletarianum, Mez.

May, September. 
Holous mollis, L. - Nat. Ord. Graminaceae.

July, August.

Hordeum murinum, L. - Nat. Ord. Graminaceae. Syn. Hordeum leporinum, LK.; Hordeum pseudo-murinum, TAPP. Almost all the year.

Hyacinthus comosus, L. - V. Muscari comosum, MiLL.

Hyacinthus Racemosus, L. - V. Muscari racemosum, MiLL.

Hyosciamus albus, L. - Nat. Ord. Solanaceae. Syn. Hyosciamus aureus, AuL. On the old walls and rocks, near the sea. April July.

Hypericum Androsaemum, L. - Nat. Ord. Hypericineae. Syn. Androsaemum officinale, ALL. May, July.

Hypericum perforatum, L. - Nat. Ord. Hypericineae. Syn. Hypericum officinarum, CR.; Hypericum vulgare, LAM. Vulgo Erba gatta.

It has a medicinal property, viz purgative; the peasants boil it with a little 
olive oil and anoint figs with it so that pilferers receive the punishment they deserve.

Yellow flowers May, August.

InUla conysaea, Lam. - V. Pulicaria dysenterica, GaERT.

Inula Dysenterica, L. - - V. Pulicaria dysenterica, Gaert.

Inula graveolens, Desf. - Nat. Ord. Compositae. Syn. Cupullaria graveolens, GR. et GoDR.; Erigerom graveolens, L. September, October.

Inula hirta, L. - Nat. Ord. Compositae. Syn. Aster hirtus, ALL.; Inula montana, POLL.

July, August.

Inula viscosa, ArT. - Nat. Ord. Compositae. Syn. Erigerom viscosum, L.; Copularia viscosa, Gr. et Godr. Vulgo Nasca. August, October.

Iris florentina, L. - Nat. Ord. Iridaceae. Very rare in the wild state. Capo Santa Croce. April, May. 
Juniperus communis, L. - Nat. Ord. Coniferae. Vulgo Zenebrin.

There are some other species which I have not yet studied.

February, March.

Knautia arvensis, Coult. - V. Scabiosa arvensis. L.

Lactuca saligna, L. - Nat. Ord. Compositae. Syn. Lactuca adulterina, GR.

June, September.

Lamarckia aurea, Moknch. - Nat. Ord. Graminaceae. Syın. Cynosurus aureus, L. May.

Lamium purpureum, L. - Nat. Ord. Labiatae.

March, May.

Lathyrus setifolius, L. - Nat. Ord. Leguminosae.

On the olive terraces. April, May.

Lathyrus silvestris, L. - Nat. Ord. Leguminosae.

June, August.

Lavandula latifolia, VILL. - Nat. Ord. Labiatae. Syn. Lavandula spica, DC. 
Monte San Bernardo.

It is at a lower level than the lavandula officinalis. August, October.

Lavandula officinalis, CH. - Nat. Ord. Labiatae.

Madonna della Guardia. June, July.

Lavandula sPica, DC. - V. Lavandula latifolia, VILL.

Lavandula stoechàs, L. - Nat. Ord. Labiatae.

Begins at a lower level than Lavand. off. and prefers dry and withered sites. January, May.

LeOPOLdia COMOSA, PARL。 - V. Muscari comosum; Mill.

Lepidium Draba, L. - Nat. Ord. Cruciferae. Syn. Cochlearia Draba, L.

On the railway sides. April, May.

Lepidium graminifolium, L. - Syn. Lepidium iberis, ALL.

Very common on the roadsides near the town. 
Leucanthemum vulgare, LAM. - Nat. Ord. Compositae. Syn. Chrysanthemum leucanthemum, L. June, July.

Limodorum abortivum, Sw. - Nat. Ord. Orchidaceae. Syn. Epipactis abortiva, ALL.; Orchis abortiva, L.; Limodorum sphaerolobium, VIV.

May.

Linaria commutata, BERNH. - Nat. Ord. Scrofulariaceae. Syn. Linaria greca, Schav.; Linaria caulirhisa, Delile; Linaria radicans, LE GALL.

Under olive trees. May, June.

Linaria cymbalaria, MrL. - Nat. Ord. Scrofulariaceae.

On the old walls near the town. May, October.

Linum angustifolium, Huds. - Nat. Ord. Geraniaceae. Syn. Linum pyrenaicum, Pourr, L.

June, July.

Linum catharticum, L. - Nat. Ord. Geraniaceae.

May, September. 
Linum Gallicum, L. - Nat. Ord. Geraniaceae. Syn. Linum aureum, WALD. et Kit. May, August.

LiNum HIRSUTum, DC. - V. Linum viscosum, L.

Linum strictum, L. - Syn. Linum corymbulosum, RchB.

May, August.

Linum tenuifolium, L. - June, July.

Linum viscosum, L. - Syn. Linum hirsutum, DC.

May, July.

Lithospermum arvense, L. - Nat. Ord. Borraginaceae.

Common under olive trees. April, June.

Lolium perenne, L. - Nat. Ord. Graminaceae. Syn. Lolium tenue, L.; Lolium cristatum, PERs.

June, October.

Lonicera Caprifolium, L. - Nat. Ord. Caprifoliaceae. Syn. Lonicera stabiana, PASQ.; Lonicera implexa, AIT.

$$
\text { May, June. }
$$


Lotus corniculatus, L. - Nat. Ord. Leguminosae.

All the summer.

- Lotus edulis, L. - Nat. Ord. Leguminosae. Syn. Lotus preslii, Ten. Capo Santa Croce. April, May.

Lotus ReCtus, L. - V. Dorycnium rectum, DC.

Lychnis alba, Milu. - Nat. Ord. Caryophylleae. Syn.Lychnis dioica, L.; Lychnis vespertina, SIBTH., ARD.; Lychnis pratensịs, SP.

May, August.

Lychnis Flos Jovis, LAM. - Nat. Ord. Caryophylleae. Syn: Agrostemma FlosJovis, L.

Found once by Prof. Gentile on the sands near the villa Garibaldi. June, July.

Lychnis githago, LAM. - Nat. Ord. Caryophylleae. Syn. Agrostemma githago, L. May, June.

Lythrum salicaria, L. - Nat. Ord. Ly- . thracieae. June, August. 
Malcolmia parviflora, DC. - Nat. Ord. Cruciferae.

May, June.

Malva silvestris, L. - Nat. Ord. Malvaceae. Syn. Malva hirsuta, Viv.; Malva vulgaris, TEN.

May, July.

Marchantia polymorpha, L. - Nat. Ord. Jungermanneae.

Summer.

Medicago litoralis, RHODE. - Nat. Ord. Leguminosae.

$$
\text { May, June. }
$$

Medicago lupulina, L. - Syn. Medicago arenaria, Ten.

All the summer.

Medicago marina, L. - Syn. Medicago cordata, LAM. May, July.

Medicago orbicularis, ALL. - Syn. Medicago applanata, WiLld. May, June.

Medicago sativa, L. - June, August. 
Melilotus Italica, LAM. - Nat. Ord. Loguminosae. Syn. Melilotus rotundifolia, TEn.

April, May.

Melissa officinalis, L. - Nat. Ord. Labiatae. Syn. Melissa altissima, Siвтн.; Melissa cordifolia, Pers.; Melissa hirsuta, HoRNE.

June, September.

IIentha aquatica, L. - Nat. Ord. Labiatae. Syn. Mentha acutifolia, Sm.; Mentha aquatica var. hirsuta, L.; Mentha dubia, VILL.; Mentha purpurea, Hosth.; Mentha sativa, Sm. Julý, August.

Mentha rotundifolia, L. - Nat. Ord. Labiatae. Syn. Mentha macrostachia, TEn.; Mentha rugosa, Lam. July, September.

Mercurialis annua, L. - Nat. Ord. Euphorbiaceae.

All the year.

Mespilus oxyacantha, All. - V. Cratego oxycantha, L. 
Mespilus germanica, L. - Nat. Ord. Rosaceae.

Cultivated. May, June.

Millium multiflorum, CAv. - Nat. Ord. Graminaceae. Syn. Piptatherum multiflorum, P. B.; Agrostis miliacea, L.

Summer and Autumn.

Molinia serotina, M. et K. - Nat. Ord. Graminaceae. Syn. Diplachne serotina, Lk. August, September.

Muscari comosum, MiLL. - Nat. Ord. Liliaceae. Syn. Hyacinthus comosus, L.; Leopoldia comosa, PARL.

April, May.

Muscari racemosum, MiLL. - Nat. Ord. Liliaceae. Syn. Hyacinthus racemosus, L. March, April.

Myagrum paniculatum, L. - V. Neslia paniculata, DEsv.

Myosotis intermedia, Lk. - Nat. Ord. Borraginaceae. Syn. Myosotis arvensis, M. Very common under olive trees. April, May.

Myrtus communis, L. - Nat. Ord. Myrtaceae. May, June. 
NARCISSUS BICOLOR, LAP. - V. Ajax pseudonarcissus, Haw.

Narcissus festalis, Salisb. - V. Ajax pseudo-narcissus, Haw.

NARCISSUS MAJOR, LoIs. - V. Ajax pseudonarcissus, Haw.

Narcissus Pseudo-Narcissus, L. - V. Ajax pseudo-narcissus, Haw.

Narcissus Radians, LaP. - V. Ajax pseudonarcissus, Haw.

Narcissus sexangularis, Roem. - V. Ajax pseudo-narcissus, HAw.

Narcissus Tazzetta, LoIs. - Nat. Ord. Amaryllidaceae.

Villa Gonghe. March, April.

Nasturtium officinale, BR. R. - Nat. Ord. Cruciferae. Syn. Sisymbrium nasturtium, L.

In the bed of torrents. May, August.

Nerium oleander, L. - Nat. Ord. Apocinaceae.

On the Capo Santa Croce. 
Very common on the bed of the Merula at Andora.

June, July.

Neslia paniculata, Desv. - Nat. Ord. Cruciferae. Syn. Crambe paniculata, ALL.; Myagrum paniculatum, L. .

May, June.

Nigella Damascena, L. - Nat. Ord. Ranunculaceae.

Under olive trèes. May, July.

Olea. - Cultivated tree, many species.

Omphalodes verna, MoEnch. - Nat. Ord. Borraginaceae. Syn. Cynoglossum omphalodes, L.

- March, April.

Onobrychis saxatilis, ALL. - Nat. Ord. Leguminosae. Syn. Hedysarum saxatile, L.; Onobrychis arenaria, DC.; Hedysarum supinum, Сн.; Hedysarum herbaceum, LAP. June, July.

Ononis minutissima, L. - Nat. Ord. Leguminosae. Syn. Ononis barbata, CAv.; Ononis saxatilis, LAM. 
Almost all the year, in arid places, very common.

Ononis spinosa, L. -- Nat. Ord. Leguminosae. Syn. Ononis arvensis et antiquorum, ALL.; Ononis campestris, K.; Ononis antiquorum, VILL.; Ononis legitima, Des. June, July.

OpHRYs ANTHROPOPHORA, L. - V. Aceras antropophora, ALL.

Ophrys aranifera vàr atrata, LINDL. Nat. Ord. Orchidaceae.

February, April.

Ophrys fusca, Lk. - Nat. Ord. Orchidaceae.

I found only one sample on the island Gallinara, the $1^{\text {st }}$ of May, which remained to $M^{r}$ Strafforello of Porto Maurizio.

OrChis ABortiva, L. - V. Limodorum abortivum, Sw.

Orchis aNthropophora, AlL. - V. Aceras anthropophora, BR. R.

Orchis coriophora, L. - Nat. Ord. Orchidaceae, Syn. Orchis fragrans, PoLL. Madonna della Guardia. May, June. . 
Orchis fragrans, Poll. - V. Orchis coriophora, L.

Orchis Longibracteata, Viv. - V. Barlia longibracteata, PARL.

Orchis Morio, L. - Syn. Orchis picta, LoIs. April, May.

Orchis papilionacea, L. - Syn. Orchis decipiens, Branc.; Orchis rubra, JAC̄̄., All. May.

Orchis provincialis, BALB. - Villa Gonghe, $4^{\text {th }}$ May 1891.

Flowers in April.

Orchis pyramidalis, L. - V. Anacamptis pyramidalis, RicH.

Orchis sambucina, L. - Found by Mr. Leutwein in the Roman Road towards Albenga. April, May.

Orchis tridentata, Scop. - Syn. Orchis cercopitheca, Lam.; Orchis Corsica, VIv.; Orchis Hanrici, Henon; Orchis Scopoli, Timв.; Orchis simia, Vill.; Orchis tenoreana, Guss.; Orchis variegata, ALL.; Orchis lactea, PoIrr. April, May. 
Origanum vulgare, L. - Nat. Ord. Labiatae.

Very common. July, September.

Orlaya grandiflora, Hoff. - V. Daucus grandiflorus, $\mathrm{B}$. et $\mathrm{H}$.

Orlaya marittima, K. - Daucus maritimus, GAERT:

Orobanche cruenta, BERT. - Nat. Ord. Orobanchaceae. Syn. Orobanche caryophyllacea, ScHLEICH; Orobanche concolor, Bor.; Orobanche gracilis, Sm.; Orobanche lobelii, NouL.; Orobanche major, DubY, All.; Orobanche vulgaris, Gaud. - May, June.

Oxalis acetosella, L. - Nat. Ord. Geraniaceae. Syn. Oxys acetosella, ALL.; Oxalis alba, LAMB.

Not rare. April, May.

Pallenis spinosa, Cass. - V. Astericus spinosus, Gr. et Godr.

Pancratium maritimum, L. - Nat. Ord. Amaryllidaceae.

See the full description. July to September. 
Panicum viride, L. - V. Setaria viridis, $P$. et $B$.

Papaver rhoeas, L. - Nat. Ord. Papaveraceáe. May.

Papaver somniferum, L. - Cultivated April, May.

Papaver setigerum, DC. - May.

Parictaria officinale, L. - Nat. Ord. Urticaceae.

Almost all the year, round the old walls.

Paronychia argentea, LAM. - Nat. Ord. Paronychiaceae.

On the old road of Santa Croce, and in that of Solva.

March, May.

Phagnalon saxatile, L. - Nat. Ord. Compositae. Syn. Conyza saxatilis, L., ALL.

April, June; on dry sites.

Phagnalom sordidum, DC. - Syn. Conyza sordida, L., ALL.

May, June. 
Phalangium liliago, Schreb. - Nat. Ord. Lilieceae. Syn. Anthericum liliago, L. Capo Mele; May, June.

Phyllirea variabilis var. augustifolia, Timb. - Nat. Ord. Oleaceae. April, May.

Physospermum aquilegifolium, K. Nat. Ord. Umbelliferae.

July, August.

Phytolacca decandra, L. - Nat. Ord. Phytolaceae.

Near old and ruined walls. July, October.

Picridium vulgare, Desf. - Nat. Ord. Compositae. Syn. Scorsonera picroides, L.; Sonchus picroides, ALL. May, October.

Picris hieracioides, L. - Nat. Ord. Compositae. Syn. Picris lappacea, LAPP.

( Pinardia coronaria, Less. - V. Chrysanthemum coronorium, L.

Pinus maritima, Lam. - V. Pinus pinaster, SOLAND. 
Pinus pinaster, Soland. - Nat. Ord. Coniferae. Syn. Pinus maritima, LAM.; Pinus syrtica, THore.

Very abundant. April, May.

Pinus pinea, L. - Nat. Ord. Coniferae. Syn. Pinus sativa, BauH.

There are still two more species which I have not y'et examined.

Piptatherum multiflorum, P. B. - V. Milium multiflorum, CAv.

Pistacea lentiscus, L. - Nat. Ord. Anacardiaceae. April, May.

Pistacia terebinthus, L. - Nat. Ord. Anacardiaceae.

On the country roadsides, at some distance from the sea: in the whole territory.

$$
\text { April, May. }
$$

Pisum. - There are some cultivated specimens.

Plantago arenaria, W. et K. - Nat. Ord. Plantagineae. Syn. Plantago indica, L.; Plantago psyllium, ALL.

$$
\text { June, July. }
$$


Plantago cynops, L. - Syn. Plantago genevensis, Porrr.; Plantago sufruticosa, LAM.

June, July.

Plantago lanceolata, L. - Syn. Plantago lanata, Hosth.; Plantago altissima, L.; Plantago eriophora, HoFF.

Plantago major, L. - Syn. Plantago intermedia, GIL.

Poa maritima, Pourr. - Nat. Ord. Graminaceae. V. Sclerochloa maritima, LK.

PoA RIGIDA, L. - V. Sclerochloa rigida, GRISS.

Polycarpon tetrapyllum, L. - Nat. Ord. Paronychieae. May, June.

Polygala vulgaris, L. - Nat. Ord. Polygaleae. May, June.

Polygonum aviculare, L. - Nat. Ord. Polygonaceae. Syn: Polygonum arenarium, Lors.; Polygonum graminifolium, WiERZB.

June, October. 
Pölygonum litorale, Lk. - Nat. Ord. Polygonaceae. July, August.

Polygonum maritimum, L. - Nat. Ord. Polygonaceae.

Almost all the year.

Populus alba, L. - Nat. Ord. Saliceae. In some torrents, and in gardens, as an ornamental tree.

February.

Portulaca oleracea, L. - Naț. Ord. Portulaceae. Vulgo Porcellana.'

Almost all the year.

Posidonia caulina, KöN. - Nat. Ord. - Naiadaceae. Syn. Zostera oceaniça, L.; Posidonià oceanica, DeL.

Bears fruit in March and April; it forms large cloump on the bottom of the sea.

October.

Potamogeton pusillus, L. - Nat. Oŕd. Najadaceae.

Grows upon the river banks and in stagnant pools. I have found many. samples on the beach after heavy rain; they came evidently from the rivers. 
Potentilla recta, L. - Nat. Ord. Rosaceae.

May, June.

Potentilla reptans, L. - Summer.

Poterium sanguisorba, L. - Nat. Ord. Rosaceae. Syn. Sanguisorba garganica, BerT.; Sanguisorba dictyocarpum, SP.

June, July.

Primula vulgaris, Huds. - Nat. Ord. Primulaceae. Syn. Primula acaulis, ALL.; Primula veris var. acaulis, L.

It is not yet in my herbarium but some English gentlemen have found it in the torrent Barbana.

Prumus spinosa, L. - Nat. Ord. Rosaceae.

Santa Croce, and elsewhere. Many kinds are cultivated and form the infinite variety of plums, almonds, peaches, and cherries. Also the Laurocerasus belongs to this family.

March, April.

Psoralea bituminosa, L. - Nat. Ord. Leguminosae. Syn. Psoralea palaestina, Moris. Junie, July. 
Pterotheca nemausensis, CASS. - Nat. Ord. Compositae.

Almost all the year.

Pulicaria dysenterica, GAERT. - Nat. Ord. Compositae. Syn. Aster dysentericus, Alc.; Inula dysenterica, L.

July, October.

Punica granatum, L. - Nat. Ord. Myrtaceae.

There is another cultivated species. June, July.

Pyrus. - There are numerous species, cultivated "with the name Pear, Apple, Service.

Quercus ilex, L. - Nat. Ord. Cupuliferae. Vulgo Erxiu.

April, May.

Quercus robur, L. - Nat. Ord. Cupuliferae. Vulgo Ruve.

More frequent than the preceding, some woods consist mainly of it.

Ranunculus aquatilis, var. submer sus, L. - Nat. Ord: Ranunculaceae. 
In the stagnant pools of the torrents not common here, but abundant on the Merula torrent near the Roman bridge. Small white flowers. March, April.

Ranunculus bulbosus, L. - Nat. Ord. Ranunculaceae.

Yellow flowers. Very common under the olive groves.

April, June.

Ranunculus ficaria, L. - Nat. Ord. Ranunculaceae. Syn. Ficaria ranunculoides, MoENCH.

Yellow flowers; very common. January, May.

Ranunculus muricatus, L. - Nat. Ord. Ranunculaceae.

In damp places. Yellow flowers. April May.

Ranunculus repens, L. - Nat. Ord. Ranunculaceae.

In damp places. Yellow flowers. April, June.

Ranunculus sceleratus, L. - Nat. Ord. Ranunculaceae.

Common. May, June. 
Raphanus Landra, MoretTI. - Nat. Ord. Cruciferae. Syn. Rapistrum arvense, Alt.; Raphanistrum Landra, DC.

Yellow flowers, some samples, more rare, have them of a rosy hue. Very common on the olive terraces.

April, May.

Reseda lutea, L. - Nat. Ord. Resedaceae. Syn. Reseda mucronata, Ten.

Along mountain roads, under olive groves, in arid places.

May, August.

Reseda phyteuma, L. - Nat. Ord. Resedaceae.

On the Moglio road where it is found at Liggia.

May, June.

Rhagadiolus stellatus, GAERT. - Nat. Ord. Compositae.

Little yellow flowers. Road to Villa Napier. April, June.

Rhamnus alaternus, L. - Nat. Ord. Ramnaceae.

Bush of two or three metres in height, leaves tough, evergreen, elliptical, greenish flowers. Rocks and wild places and also on the olive terraces. 
Rhus cotinus, L. - Nat. Ord. Anacardiaceae. Vulgo Carcabecchi; ital. Scotano. In arid places. May, June.

Rosa canina, L. - Nat. Ord. Rosaceae. Very common. There are two more species which I have not yet classified. May, June.

Rosmarinus officinalis, L. - Nat. Ord. Labiatae.

Castelletti till to Porto Salvo. March, October.

Rubia peregrina, L. - Nat. Ord. Rubiaceae. Syn. Rubia Requiennii, Duby. On the old walls of the olives. May, June.

Rubus discolor, W. et N. - Nat. Ord. Rosaceae. Syn. Rubus dalmaticus, Tratt.; Rubus abruptus, LindL.; Rubus candicans, Fr.; Rubus fruticosus, Sm. Vulgo Ruveu.

Very common on the edges of the torrents. June, July.

Rumex maritimus, L. - Nat. Ord. Polygonaceae.

On the torrents. July, September. 
Ruta graveolens, L. - Nat. Ord. Rutaceae. Syn. Ruta legitima, JACQ.; Ruta tenuifolia, DEsF.

Remarkable for its bad smell; very common. June, July.

Salix alba, L. - Nat. Ord. Salicaceae. March, April.

Salix babilonica, L. - Vulgo Salice piangente.

Cultivated in the gardens.

Salsola Kali. - Nat. Ord. Chenopodiaceae. Syn. Salsola decumbens, LaM.; Salsola spinosa, LaM.

July, August.

Salvia Clandestina, Benth. - V. Salvia verbenaca, $\mathrm{L}$.

Salvia sclarea, L. - Nat. Ord. Labiatae. Vegliasco and Capo Mele. May, July.

Salvia verbenaca, L. - Nat. Ord. Labiatae. Salvia clandestina, BENTH. Syn. of Salvia horminoides. April, October.

Sambucus nigra, L. - Nat. Ord. Caprifoliaceae, June. 
Samolus valerandi, L. - Nat. Ord. Primulaceae.

May, July.

Sanguisorba garganica, Bert. - V. Poterium sanguisorba, L:

Sanguisorba dictocarpum, Sp. - V. Poterium sanguisorba, L.

Saponaria ocymoides, L. - Nat. Ord. Caryophylleae. Syn. Saponaria repens, LAM.

Flowers of a rosy hue. Madonna del Vento, and in many places. May, June.

Scabiosa arvensis, L. - Nat. Ord. Dipsaceae. Syn. Knautia arvensis, Coult.; Scabiosa polymorfa, ScHm.; Scabiosa variabilis, Schultz.

June, July.

Scabiosa leucantha, L. - Nat. Ord. Dipsaceae. Syn. Scabiosa mediteranea. VIv.

Scabiosa pyrenaica, ALL. - Nat. Ord. Dipsaceae. July, August. 
Scandix infesta, L. - Caucalis infesta.

Scandix pecten Venêris, L. - Nat. Ord. Umbelliferae. Syn. Myrrhis PectenVeneris, ALL. April, June.

Schaenus mucronatus, L., All. - V. Cyperus capitatus, VAND.

Scilla italica, L. - Nat. Ord. Liliaceae. Syn. Scilla Bertolonii, D.

In the torrents of Reg. Gonghe and San Bernardo; bleu flowers.

March, April.

Scilla italica alba. - It is a variety with white flowers, never described by anybody to my knowledge: found together with the preceding.

Scilla maritima, L. - V. Urginea Scilla, STEIN.

Sclerochloa maritima, Lk. - Nat. Ord. Graminaceae. Syn. Poa maritima, PourR.; Scleropoa maritima, PARL。

May. 
Sclerochloa rigica, PANZ. - Nat. Ord. Graminaceae. Syn. Poa rigida, (Kriss.; Scleropoa rigida, GRiss.

May, July.

Scolymus hispanicus, L. - Nat. Ord. Compositae. Syn. Scolymus maculatus, All., L.

June, July.

Scorpiurus sulcata, L. - Nat. Ord. Leguminosae.

Summer.

SCORSONERA PICROIDES, L. - V. Picridium vulgare, DesF.

Scrofularia aquatica, L. - Nat. Ord. Scrofulariaceae. Syn. Scrofularia Balbizii, HoRn.; Scrofularia oblongifolia, LoIs.

In the torrents.

May, June.

Scrofularia canina, L. - Nat. Ord. Scrofulariaceae. Syn. Scrofularia lucida, AlL.: scrofularia multifida, LAM.

Uncultivated places, not far from the sea. May, June.

Securidaca legitima, Gaert. - V. Bonaveria securidaca, Rchr. 
SeCurigera Coronilla, DC. - V. Bonaveria securidaca, "Rchв.

Sedum acre, L. - Nat. Ord. Crassulaceae.

June, July.

Sedum dasyphyllum, L. - Nat. Ord. Crassulaceae.

May, June.

Sedum nicense, All. - Nat. Ord. Crassulaceae. Syn. Sedum altissimum, PorrR.; Sedum ochroleucum, VILL.

On almost all the terrace walls of the olive groves, and in uncultivated places. June, August.

Senecio cineraria, DC. - Nat. Ord. Compositae. Syn. Senecio maritimus, Rchв.; Cineraria maritima, L.; Cineraria ceratophylla, CYr.

Capo Santa Croce, Capo Mele, Porto Salvo. Very common.

- June, July.

Senecio jacobea, L. - Nat. Ord. Compositae.

June, August. 
Senecio vulgaris, L. - Nat. Ord. Compositae. Syn. Senecio denticulatus, NoLDT.

All the year; very common in cultivated grounds.

Serapias cordigera, L. - Nat. Ord. Orchidaceae.

April, May.

Serratula tinctoria, L. - Nat. Ord. Compositae.

August, October.

Sesleria argentea, SAvI. - Nat. Ord. Graminaceae. Syn. Sesleria cylindrica, DC.; Sesleria elongata, Host.

June, July.

Setaria viridis, P. B. - Nat. Ord. Graminaceae. Syn. Panicum viride, L., ALL. June, October.

Sherardia arvensis, L. - Nat. Ord. Rubiaceae.

Common in the olive groves. April, July.

Sideritis romana, L. - Nat. Ord. Labiatae. Syn. Sideritis spathulata, LAM. June, July. 
Silene inflata, Sm. - Nat. Ord. Caryophylleae. Syn. Cucubalus Behen, L., AlL.

May, June.

Silene italica, PERs. - Nat. Ord. Caryophylleae. Syn. Cucubalus italicus, L., All.

May, June.

Sinapis arvensis, L. - Nat. Ord. Cruciferae. Syn. Sinapis orientalis, Auct.

On the olive tertraces. April, July.

Sisymbrium Nasturtium, L. - V. Nasturtium officinale, BR. R.

Sisymbrium officinale, ScOP. - Nat. Ord. Cruciferae. Syn. Erysimum officinale, L.

May, October.

Smilax aspera, L. - Nat. Ord. Asparagaceae. Vulgo Razza, Salsapariglia.

September, October.

Smyrnium olusastrum, L: - Nat. Ord. Umbelliferae. Syn. Smyrnium Mathioli, T. April, May. 
Solanum dulcamara, L. - Nat. Ord. Solanaceae. Syn. Solanum scándens, LAM.

Moglio road, in the bed of one torrent, - near Villa Merella.

- June, August.

Solanum nigrum, L. - Nat. Ord. Solanaceae. Syn. Solanum pterocaulon, Rchi. Very common, almost all the year.

Sonchus oleraceus, L. - Nat. Ord. Compositae. Syn. Sonchus laevis, BARTL.; Sonchus glaucescens, JoRD.; Sonchus ciliatus, LAM.

Common in cultivated places. May, October.

SONCHUS PICROIDES, ALL. - V: Picridium vulgare; DESF.

Spartium junceum, L. - Nat. Ord."Leguminosae.

Uncultivated places.

May, July.

Specularia speculum, DC. - Nat. Ord. Campanulaceae. Syn. Campanula speculum, L.

Madonna della Guardia.

May, July. 
Spiranthes antunnalis, RICH. - Nat. Ord. Orchidaceae.

September, October.

Sporobolus pungens, Kтн. - Nat. Ord. Graminaceae. Syn. Agrostis pungens, SCHREB.

Summer.

Stachys recta, L. - Nat. Ord. Labiatae. Syn. Stachys procumbens, Lam.; Stachys sideritis, VILL.; Stachys bufonia, Тн. June, October.

Staehelina dubia, L. - Nat. Ord: Compositae.

June, July.

Stellaria media, VILL. - Nat. Ord. Caryophylleae. Syn. Alsine media, L., Alu. Almost all the year.

Sternbergia lutea, GAwL. - Nat. Ord. Amaryllidaceae. Syn. Amaryllis lutea, L. Reg. Vegliasco.

September, Ôctober.

Symphytum tuberosum, L. - Nat. Ord. Borraginaceae.

April. 
Tamus communis, L. - Nat. Ord. Dioscoreaceae.

Torrent Cappuccini.

April, May.

Taraxacum vulgare, LAM. - Nat. Ord. Compositae. Ital. Soffione.

March, October.

Teucrium chamaedrys, L. - Nat. Ord. Labiatae. Syn. Teucrium officinale, LAM. May, September.

Teucrium fruticans, L. - Nat. Ord. Labiatae.

- Only on the western side of Capo Mele. Autumn, winther, spring.

Teucrium Iva, L. - V. Aiuga Iva, Schreb.

Teucrium montanum, L. - Nat. Ord. Labiatae. Syn. Teucrium supinum, L. May, August. :

Teucrium Polium, L. - Nat. Ord.: Labiatae. Syn. Teucrium capitatum, ALI. . - May, August.

Theligonum Cynocrambe, L. - Nat. Ord. Urticaceae. March, April. 
Thesium divaricatum, JAN. - Nat. Ord. Santalaceae.

June, August.

Thesium hunifusum, DC. - Nat. Ord. Santalaceae. Syn. Thesium alpinum, TH.; Thesium Hussenoti, Huss. June, July.

Thesium tenuifolium, RchB. - Nat. Ord. Santalaceae. June.

Thlaspi bursa pastoris, L. - Nat. Ord. Cruciferae. Syn. Capsella bursa pastoris, MOENCH.

Almost all the year.

Thymelea Gnidium, All. - V. Daphne Gnidium.

Thymus vulgaris, L. - Nat. Ord. La- kiatae.

There is another variety on the Capo Santa Croce, with white flowers. March, April.

Torilis helvetica, GM. - V: Caucalis infesta. 
'T'ORILis Infesta, Wallr. - V. Caucalis infesta.

Tragus racemosus, HALL. - Nat. Ord. Graminaceae. Syn. Cenchrus racemosus, L. 。 June, August.

Tribulus terrestris, L. - Nat. Ord. Rutaceae.

May, October.

Trifolium agrarium, L."-- Nat. Ord. Leguminosae. Syn. Trifolium campestre, Schreb.; Trifolium aureum, Poll., Gr. et GODR.

June, July.

Trifolium angustifolium, L. - Nat. Ord. Leguminosae. June, July.

Trifolium arvense, L. - Nat. Ord. Leguminosae. Syn. Trifolium Brittingerii, Werтt.; Trifolium gracile, Тн. Maý, June.

Trifolium pratense, L. - Nat. Ord. Leguminosae. Syn. Trifolium heterophyllum, LeJ.

May, September. • 
Trifolium repens, L. -- Very common; April, July.

Trifolium rubens, L. - Nat. Ord. Leguminosae.

May, July.

Trifolium scabrum, L. - Common in dry and withered sites.

May, June.

Trifolium stellatum, L. - Nat. Ord. Leguminosae.

April, June.

Triticum ovatum. - V. Aegilops ovata, L.

Triticum RePens, L. - V. Agropyrum repens, P. B.

Tulipa clusiana, DC. - Nat. Ord. Liliaceae.

It is very common at Andora, here we find it only cultivated.

March, April.

Tussilago farfara, L. - Nat. Ord. Compositae.

February, April.

Alassio and its Flora 
Umbilicus pendullinus, DC. - Nat. Ord. Crassulaceae. Syn. Cotyledon umbilicus, L.

May, June.

Uriginea scilla, STEIN. - Nat. Ord. Liliaceae. Syn. Scilla maritima, L. August, October.

Urospermum Daleschampii, DESF. Nat. Ord. Compositae. Syn. Tragopogon Dalescha mpii. May, July.

Urospermum picroides, Desf. - Nat. Ord. Compositae. Syn. Tragopogon picroides, L.

May, July.

Urtica dioica, L. - Nat. Ord. Urticaceae. Spring, autumn.

VAleriana Rubra, L. - V. Centhrantus ruber, DC.

Valerianella dentata, Poll. - V. Valerianella Morisoni, DC.

Valerianella Morisoni, DC. - Nat. Ord. Valeriancac. May, Junc. 
Verbascum blattaria, L. - Nat. Ord. Scrofulariaceae.

June, July.

Verbascum floccosum, WETK. - Nat. Ord. Scrofulariaceae. Syn. Verbascum heterophyllum, Moric.; Verbascum laxiflorum, PresL.; Verbascum phlomoides, Thuill.; Verbascum pulverulentum, VILL.

Summer.

Verbascum Thapsus, L. - Nat. Ord. Scrofulariaceae. Syn. Verbascum Schraderi, Mey.; Verbascum neglectum, Guss.; Verbascum densiflorum, PoLl. Vulgo Tasso-barbasso.

June, September.

Verbascum sinuatum, L. - Nat. Ord. Scrofulariaceae.

June, October.

Verbena officinalis, L. - Nat. Ord. Verbenaceae.

May, August.

Veronica agrestis, L. - Nat. Ord. Scrofulariaceae. Syn.Veronica pulchella, BAsT.; Veronica didyma, Ten.

May. 
Veronica cymbalaria, BOD. - Nat. Ord. Scrofulariaceae. Syn. Veronica cymbalariaefolia, VAHL.; Veronica panormitana, TEN.

February, May.

Veronica didyma, Ten. - Nat. Ord. Scrofulariaceae. Syn. Veronica polita, Fr. February, March.

Veronica officinalis, L. - Nat. Ord. Scrofulariaceae. Syn. Veronica acutiflora, LAP.

Viburnum Tinus, L. - Nat. Ord. Caprifoliaceae.

Bush of 1 or 2 metres in height. I wish to enter it amongst our own plants because I think it exists on the Capo Santa Croce, on the way to Albenga in which place I have found almost all the plants of the island Gallinaria.

Isola Gallinaria. April.

Vicia cracca, L. - Nat. Ord. Leguminosae. Syn. Cracca major, Frank. - Vicia Gerardi, St. HiLA IRE.

May, August.

Vicia Gherardi, VILL. - Nat. Ord. Leguminosae. June. 
Vicia gemella, Crantz. - Nat. Ord. Leguminosae. Syn. Ervum tetraspermum,L.; Vicia tetrasperma, MoENCH.

April, June.

Vicia gracilis, LoIs. - Nat. Ord. Leguminosae. Syn. Ervum gracile, DC.; Ervum aristatum, RAF.; Ervum longifolium, Ten.; Ervum tenuifolium, LaG.

May, June.

Vicia hybrida, L. - Nat. Ord. Leguminosae.

April, May.

Vicia sativa, L. - Nat. Ord. Leguminosae.

May, June.

Vinca media, Hoff. et Lk. - Nat. Ord. Apocinaceae. Syn. Vinca acutiflora, BERT. March, April.

Vincetoxicum officinale, Moench. - V. Cynancum vincetoxicum, BR. $R$.

Viola alba, Bess. - Nat. Ord. Violaceae. Reg. Schiffi; Torrent of Madonna della Cuardia, opposite to the Villa Aicardi. March. 
Viola canina, L. - Nat. Ord. Violaceae. March, April.

Viola hirta var. picta, MooG. - Nat. Ord. Violaceae.

Reg. Schiff, 22 ${ }^{\text {nd }}$ March 1892. It is abundant in the wood called Bosco dell' Inferno at San Fedele (Albenga).

Viola odorata, L. - Nat. Ord. Violaceae. March, April.

Viola tricolor, L. - Nat. Ord. Violaceae. April, October.

Zostera oceanica, L. - V. Posidonia caulini, KöN.

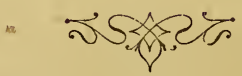


APPENDIX 



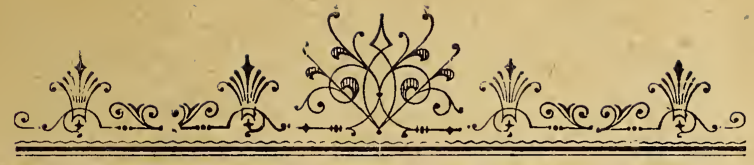

\section{APPENDIX}

Acanthus mollis, L. - Nat. Ord. Acanthaceae.

Near the Convento di San Bernardino at Albenga, a few metres distant from the high road.

March, July.

Bellis annua, L. - Nat. Ord. Compositae. Syn. Bellis dentata, DC.

At Albenga between the Cemetery and the railway.

March, April.

Carduus tenuiflorus, CuRT. - Nat. Ord. Compositae. Syn. Carduus acanthoides, Lois.; Carduus microcephalus, Gaud. Along the roads. August. 
Inula crithmoides, L. - Nat. Ord. Compositae.

At Vadino in the territory of Albenga. June, October.

Medicago arabica, L. - Nat. Ord. Leguminosac. Syn. Medicago maculata, WiLld. Leaflets heart-shaped, with the apex attached to the stalk, and with a black spot in the middle.

Reg. Serre. April, June.

Narcissus ...... (1) - Nat. Ord. Amaryllidaceae.

Leaves linear, from 5 to 7 millim. wide, longer than the scape, channel shaped, ending in a point, green.

Bulb large, globular, of about $3 \frac{1}{2}$ cent. in diameter.

Umbel with several flowers (4 in this sample); lobes of the perigon of a broad elliptical shape, and with a notch at the apex, the external three have in the middle of the notch a slight point of about 1 millim. in length which divides the angle in two, the colour is of a beau-

(1) According to the description given by Prof. Arcangeli in his FloRA ITALIANA it somewhat resembles the Narcissus Italicus, SIMS. 
tiful canary yellow, the length as long as that of the tube.

Crown about $\frac{1}{3}$ that of the laciniae; colour yellow of a deeper tint, the circumference of the euge shorter than that of the middile, almost barrel shaped.

Style longer than the superior stamens, it does not surpass the anthers of the superior stamens, arrives at the top of the anthers of the inferior stamens. Style longer than the tube, it appears with the three superior anthers and with the extremity of the three inferior at the bottom of the crown. It is detached in all its length.

Stamens are adherent in all its length to the tube.

T'ube thinner near the ovary than near the perigon.

Scape almost round, hollow, with longitudinal ridges, clear green.

Spathe scarious, about 1 centim. wide and $3 \frac{1}{2}$ long.

Reg. San Bernardo, near the Villa Bonavia 22 ${ }^{\text {nd }}$ March 1892.

Narcissus...... (1) - Nat. Ord. Orchidaceae.

(1) This is more like the Narcissus Bertolonii, PARL., according to the characteristics given by Prof. Arcangeli. 
Umbel of several flowers.

Lobes of the perigon elliptical, without a notch, pale-yellow coloured, almost white, $\frac{1}{4}$ shorter than the tube the external three mucronate.

Crown about $\frac{1}{3}$ of the lobes of the perigon, cup-shaped, of a deep yellow resembling the colour of the yolk of an egg.

Style shorter than the superior stamens and the tube, detached in all its length, and reaching the point of the inferior anthers. Only the superior anthers are entirely included in the cup of the crown.l

Tube thinner near the ovary than the perigon, longer than that of the preceding.

Scape two-angled, with longitudinal ridges, of an intense green, thinner than that of the preceding, hollow.

Spathe scarious, equal to that of the preceding.

Ophrys lutea, Cav. - Nat. Ord. Orchidaceae. Reg. Serre, below Villa Murchio. March, April.

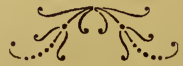


SEA WEEDS 



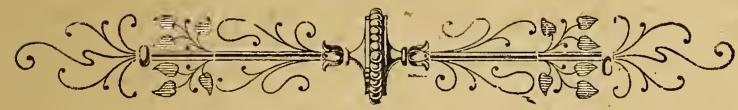

\section{SEA WEEDS}

Asperococcus bullosus, Grev.

Bornetia secundiflora, Thur.

Bryopsis tenuissima, Moris et Dntrs.

Ceramium ciliatum, Duch.

Ceramium rubrum, $A g$.

Chorda filum, Lyngh.

Chorda lomentaria, Lyngh.

Cistoseira abrotanifolia, $A g$.

Cistoseira amentacea, $J$. $A g$.

Cistoseira crinita, Dub.

Cistoseira montagnei, J. Ag.

Dictyota dichotoma, Grev.

Gastroclonium salicornium, $K$.

Gelidium corneum, Lamx.

Gracilaria dura, $A g$.

Griffithsia phyllamphora, J. Agrdh.

Gymnogongrus nicensis, Ard.

Halimeda tuna, Lamx.

Halyseris polypodioides, $A g$. 
Hypnea musciformis, Lamx.

Iania rubens, Lamx.

Laurentia pinnatifida, $A g$.

Liagora viscida, $A g$.

Nemalion lubricum, Duby.

Nytophyllum occellatum, $J$. Ag.

Nytophyllum uncinatum, $J$. $A g$.

Padina pavonia, Lam $x$.

Peyssonellia rubra, $J$. Ag.

Peyssonellia Straforelliana.

Plocamium mediterraneum, Menegh.

Phyllophora nervosa, Grev.

Rhodymenia palmetta, Grev.

Rissoella verrucolosa, $J$. $A g$.

Rytiphlaea pinnastroides, $O g$.

Sargassum hornschouchii, J. Ag.

Scinaja furcellata, $B i$.

Sphacelaria filicina, $A g$.

Udotrea desfontainii, Dec.

Ulva enteromorpha, $A g$.

Ulva lactuca, $A g$.

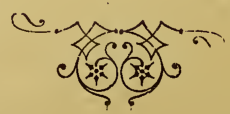




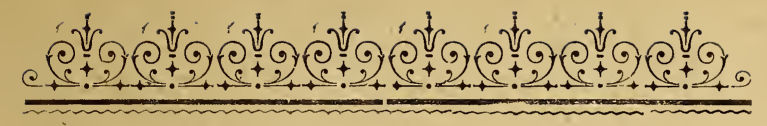

I tender my warmest thanks to Cav. Idelfonso Strafforello, a distinguished botanist, who has already won well merited laurels in the field of algology and to the illustrious Prof. Giacomo Gentile, of Porto Maurizio, an equally earnest student of natural science for the powerful assistence they have lent me for the better recognition and classification of the plants when collected; whereby they have saved me much of my time which I should otherwise have had to steal from the cares of medical profession.

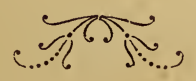



I N D E X 




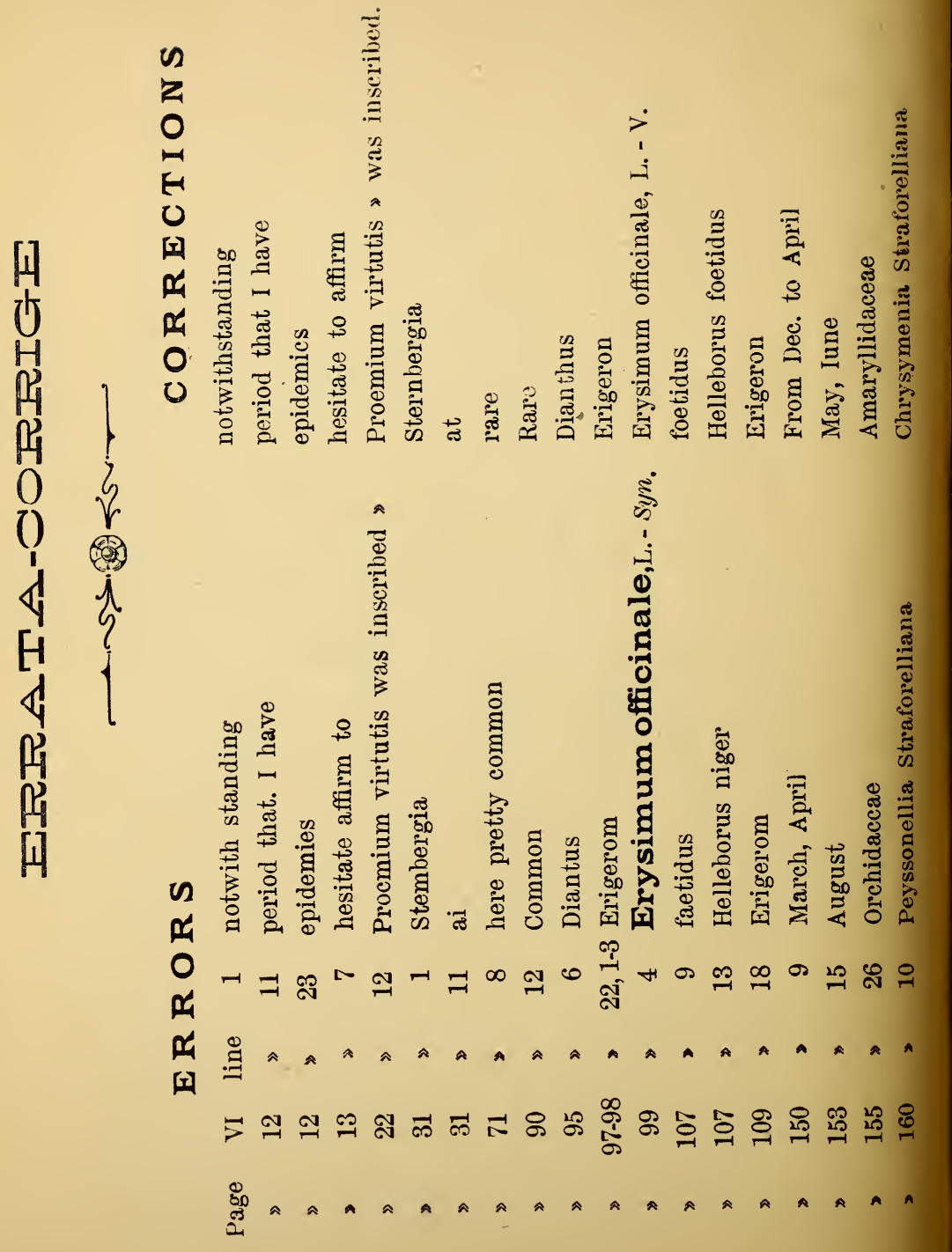




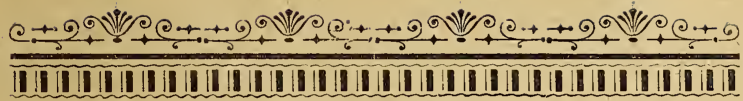

I N D E X

Preface . . . . . . . . . pag. v

Alassio: Geographical position -

Climate - Public health . . » 1

Historical sketch of Alassio . . » 15

Flora . . . . . . . . . . » 29

Alphabetical index of the plants found by the author in the.Gulf of Alassio . . . . . . . \ 57 Appendix . . . . . . . . 》 151 Sea Weeds . . . . . . . » 157

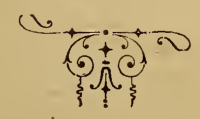





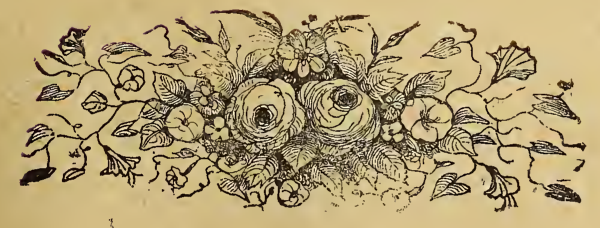




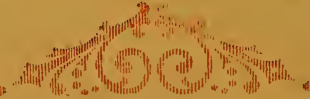

Price Fr. 2. 



